\title{
Effect of intranasally-administered adipose derived stem cells on age-related changes of rat olfactory bulb: A histological and immunohistochemical study
}

Original

Article
Nevine Bahaa, Mona H. Raafat

Histology and Cell Biology Department, Faculty of Medicine, Ain Shams University, Cairo, Egypt

\begin{abstract}
Introduction: Age-related olfactory decline is increasingly recognized to be a major health problem with no known treatment yet, reflecting on individual safety, nutrition, physical and mental well-being. Intranasal administration of adipose derived stem cells (ADSCs) could be an ideal curative strategy, bypassing the blood brain barrier with no risk for systemic exposure.

Aim: To evaluate the age related structural changes in the olfactory bulb (OB) of rats and to assess the possible therapeutic role of intranasally-administered ADSCs after different time points.

Materials and Methods: Thirty aged female rats, of two years old, in addition to five adult rats, six months old were used in this study. They were divided into group I; served as adult control group, group II; served as aged non-treated group, and group III that served as aged group treated with $1 \times 10^{6}$ of PKH26-labelled intranasal ADSCs. Rats of groups I and II were sacrificed after 14 days of the beginning of the experiment. Rats of group III were sacrificed after two hours, one, three, and 15 days respectively, five rats/time point. Dissection of OB was done at each time point, and processed for light microscopic examination after staining with $H \& E$, toluidine blue, and immunohistochemically-staining for synaptophysin and S-100B. Morphometric study and statistical analysis were also done.

Results: Aged rats showed structural degenerative changes in all layers of the OB. Intranasal administration of ADSCs reached the OB as early as two hours after administration, and managed to gradually reverse its age-induced structural damage.

Conclusion: Intranasal administration of ADSCs managed to reverse the OB structure to the adult appearance. Hence, it is recommended to include the intranasal ADSCs as a powerful therapeutic strategy for olfactory bulb dysfunction in aged individuals.
\end{abstract}

Revised: 04 August 2017, Accepted: 29 September 2017

Key Words: Adipose derived stem cells, aging, intranasal route, olfactory bulb, rats.

Corresponding Author: Nevine Bahaa, Histology and Cell Biology Department, Faculty of Medicine, Ain Shams University, Cairo, Egypt, Tel.: +201003950080, E-mail: nevine_bahaaeldine@med.asu.edu.eg.

ISSN: 1110-0559, Vol. 40, No.4

\section{INTRODUCTION}

Sense of smell plays a very important role in every day's safety, recognition of danger, interpersonal communication, and in feeling pleasure of eating and drinking ${ }^{[1]}$. Olfactory dysfunction (OD) is a common feature in elderly ${ }^{[2]}$ present in more than half of those between the ages of 65 and 80 years and more than three quarters of those over the age of 80 years $^{[3]}$. In fact, many patients with olfactory dysfunction showed signs of depression owing to limitations of many aspects of life enjoyments ${ }^{[4]}$. OD may be due to structural and functional abnormalities of the olfactory epithelium, olfactory bulb, central olfactory cortex, or basic olfactory circuit $^{[5]}$. Moreover, smell loss could be an early sign of some neurodegenerative diseases as Alzheimer's disease, Parkinson's disease, mild cognitive impairment, frontotemporal lobar degeneration, and Huntington's disease. Olfactory impairment may also progress to dementia $^{[6]}$. Thus, olfactory functioning could serve as a valid indicator of the integrity of the aging brain. Unfortunately, the symptomatic relevance and potential preclinical value of olfactory dysfunction remain disregarded by many clinicians ${ }^{[7]}$.

The concept of regenerative medicine has stimulated the development of stem cell therapies forward. This might be especially important in organs such as brain, heart and eyes which have limited regenerative abilities following injury, infarct or degenerating conditions ${ }^{[8]}$. Adipose derived stem cells (ADSCs) were recently studied as an ideal alternative source of stem cells, other than bone marrow derived mesenchymal stem cells (BM-MSCs). They have been proved to be of a substantial clinical value in diseases lacking efficient treatments as in central nervous system disorders ${ }^{[9]}$. ADSCs have significant advantages over BM-MSCs, including greater potential cell yield from patients, a less invasive harvesting procedure ${ }^{[10]}$. 
Recently, the ability of ADSCS to differentiate into many cells lineage including neuronal differentiation has been documented ${ }^{[11]}$.

The blood-brain barrier (BBB) is known to limit the penetration, thus restricting the use, of numerous therapeutic agents that have been developed to treat neurodegeneration. Emerging from this point, intranasal (IN) administration targeting delivery of therapeutics to the central nervous system (CNS) might have many benefits in the treatment of neurologic disorders ${ }^{[12]}$. Moreover, intranasal formulations successfully reach the brain. Thus, IN route of delivery might become a powerful therapeutic strategy, by passing the blood-brain barrier and minimizing systemic exposure ${ }^{[13]}$.

\section{AIM OF THE STUDY}

This study aimed to explore the histological changes of the olfactory bulb structure as a result of aging. Furthermore, it aimed to detect the possible therapeutic role of intranasal administration of ADSCs, as a novel route of stem cell delivery, on the olfactory bulb, after different time intervals of their administration.

\section{MATERIALS AND METHODS}

This study included, a number of 30 female Wistar rats, two-year old (300-350) gm, together with 5 six-months old female adult Wistar rats weighing 180-200 gm. They were purchased and housed in the Medical Research Center, Faculty of Medicine, Ain Shams University. All animals were put in wire mesh cages, with food and water ad-libitum. They were divided into three main groups as follows:

Group I (control adult group) comprised five adult rats, serving as the control adult group. These animals received single intranasal $120 \mu \mathrm{l}$ of phosphate buffered saline (PBS), equivalent to that given in group III administered as $60 \mu \mathrm{l} /$ nostril in two consecutive doses ( $30 \mu \mathrm{l}$ in each time). These rats were sacrificed after 14 days from the beginning of the experiment.

Group II (aged non-treated group) comprised five aged rats that served as the aged group. They also received PBS in same dose, and route as in group I. They were also sacrificed after 14 days from the beginning of the experiment.

Group III (aged group treated with intranasal ADSCs) comprised 25 aged rats that received intranasal PKH26-labelled ADSCs, purchased from the Medical Biochemistry Department, Faculty of Medicine, Cairo University. Five rats were then sacrificed at each of the following time points; after two hours, one day, three days, five days and 14 days.

\section{Method of intranasal delivery}

The rats were maintained in a supine position, nonanesthetized. Nasal cavity of each animal was treated once with total of $1 \times 10^{6[14]}$ of PKH26-labelled ADSCs suspended in $120 \mu \mathrm{l}$ of PBS in group III, or PBS only in groups I and II. This was done via an infantile cannula fitted onto the opening of an insulin syringe, ensuring the intranasal delivery of the stem cell suspension or the PBS solution. The rats received this dose in alternate applications of $30 \mu \mathrm{l}$ drops (left and right), twice for each nostril, at the opening of the nostrils with 5-minute intervals, allowing the animal to sniff the cell suspension or the PBS solution into the nasal cavity ${ }^{[13]}$.

\section{Histological and immunohistochemical study}

The animals were anesthetized by ether inhalation at the end of each time point. Transcardial perfusion of sterile $0.9 \%$ physiological saline, $(0.9 \% \mathrm{NaCl})$, followed by transcardial perfusion of $10 \%$ neutral buffered formalin was done into the left ventricle. Brain was dissected out and fixed in $10 \%$ neutral buffered formalin for ten days after which the olfactory bulb was separated from the frontal cortex and processed to from paraffin blocks. Serial $5 \mu \mathrm{m}$ sections were cut and stained by $\mathrm{H} \& \mathrm{E}$, toluidine blue stains ${ }^{[15]}$.

Immunofluorescence examination of the intranasallyadministered PKH26-labelled ADSCs was done to track and ensure the delivery of injected ADSCs to the olfactory bulb of aged rats of group III in all time points. Deparaffinized, non-stained sections were examined and photographed in Medical Biochemistry Department, Faculty of Medicine, Cairo University using Inverted Microscope with Fluorescence unit (Leica, Germany).

Immunohistochemical staining of paraffin sections was also done for synaptophysin using Rabbit antirat, Monoclonal anti synaptophysin primary antibody for neuronal synapses, [YE269] (ab32127) abcam, Cambridge, UK). The reaction appeared as brownish granules mainly in membranes of axons, dendrites and synaptic vesicles. Anti S-100B primary antibody was also used as a marker of mature astrocytes. It was purchased as Rabbit anti-rat, polyclonal antibody, ab34686, Abcam, Cambridge, UK). The reaction appeared as brownish granules in cytoplasm and nuclei of mature astrocytes. The immunohistochemical staining was carried out using the avidine-biotin peroxidase technique. Sections were then counterstained with hematoxylin, dehydrated, cleared, and mounted. Negative control specimens were performed after 
omitting the primary antibody. Whole brain specimens were used as positive controls for both antibodies ${ }^{[15]}$.

\section{Morphometric study and statistical analysis:}

Morphometric measurements were carried for the following parameters:

1- Mean number of glomeruli (10X).

2- Mean size of glomeruli in $\mu \mathrm{m}(20 \mathrm{X})$.

3- Mean Nissl's granules density in mitral cells (40X).

4- Mean density of glomerular synaptophysin (SYP) immunohistochemical reaction (20X).

5- Mean number of S-100B immunohistochemicallypositive mature astrocytes in all layers of $\mathrm{OB}(40 \mathrm{X})$.

All measurements were performed using Leica Qwin software program installed on a Dell PC (Texas, USA), connected to a microscope (Leica microsystem, Heerbrugg, Switzerland) in the Histology and Cell Biology Department, Faculty of Medicine, Ain Shams University, Cairo, Egypt. Measurements were taken from five different non-overlapping sections (five fields/section) from each animal in each group. The mean values and the standard deviation (SD) were calculated using SPSS statistical program version 21; IBM Corporation, NY 10589. Data were evaluated using one-way analysis of variance test (ANOVA). Data were considered significant level at $\mathrm{P}$ value less than 0.05 .

\section{RESULTS}

Examination of sections of the two hours' time point of ADSCs treated group revealed that the OB was nearly structurally identical to that of the aged non-treated group in all histological and immunohistochemical stains performed (data not shown). However, the immunofluorescent results of the two hours' treated group will be demonstrated hereafter.

\section{1- PKH26 Immunofluorescence}

On examination by fluorescence microscope, sections of the non-treated aged rats of group II showed negative immunofluorescence as expected, as this group wasn't treated by the labelled PKH26 (Fig.1a). Sections of group III revealed maximum positive fluorescence in all layers of the OB two hours after intranasal PKH26-labelled ADSCs administration, confirming the delivery of the injected cells to the OB (Fig.1b). Positive fluorescence was also detected in all other time points. However, it was apparently gradually decreasing with advancing time after intranasal ADSCs treatment at one, three and five days respectively, being minimal after 14 days of treatment (Figs. 1c, 1d, 1e,
If respectively) as compared to the two hours' time point.

\section{2- H\&E-stained sections}

Examination of the H\&E-stained sections of the control adult rats of group I revealed the regular concentric multilayered olfactory bulb organization. Superficially inwards, olfactory nerve fiber layer (ONL), glomerular layer (GL), external plexiform layer (EPL), mitral cell layer (MCL), closely associated to granule cell layer (GCL) were observed. The olfactory nerve fiber layer comprised the axons of olfactory epithelium sensory neurons. The glomerular layer consisted of multiple, roughly spherical to oval acellular synaptic islands (glomeruli), arranged in one or two rows internal to the ONL (Fig.2). Multiple interneuron juxtaglomerular cells (JG cells) were seen surrounding the glomeruli exhibiting small perikarya containing relatively large deeply stained nuclei surrounded by a thin rim of basophilic cytoplasm (Fig. 3a). Statistically, the glomeruli mean number was counted as $15.6 \pm 0.54$, mean \pm SD (Histogram 1), and their mean size was measured in $\mu \mathrm{m}$ as $359.6 \pm 12.7$, mean \pm SD (Histogram 1). The EPL showed sparsely distributed small to medium-sized multipolar tufted cells (Fig.3a). Mitral cells, having triangular or multipolar cell bodies, were the largest cells of $\mathrm{OB}$, arranged in one row in the MCL, marking the end of EPL. The granule cell layer (GCL) was occupied mainly by the small interneuron axon-less granule cells with small perikarya containing large dense rounded nuclei surrounded by scanty cytoplasm. They were arranged in multiple compact parallel lamellae; however, some scattered granule cells were also commonly observed among the mitral cells in the MCL (Fig. 3b).

Sections of the aged non-treated rats of group II revealed discontinuous, apparently thin glomerular layer (GL) with appearance of multiple areas devoid of glomeruli. Most of the remaining glomeruli were apparently small as compared to that of the adult group (Fig. 4a). Significant decrease $(P<0.05)$ in mean number and size of glomeruli was detected as compared to group I, measuring ( $4.8 \pm 0.83$ and 103.2 \pm 6.45 , Histogram 1). An apparent decrease in population of juxtaglomerular cells (Fig. 4a), as well as in the mitral and granule cells. The granule cells were seen disorganized mainly in the superficial parts of the GCL, being sparsely seen in the deeper parts (Fig. 4b). The few remaining mitral cells appeared deeply stained and smaller than those of the adult group I (Fig. 4b).

One day after intranasal ADSCs administration in aged rats of group III, the glomeruli reappeared in many areas of the GL, however, other areas were still seen devoid of glomeruli. Juxtaglomerular cell number appeared comparable to the aged group (Fig.5a). Significant increase in mean glomerularnumber and size were detected $(P<0.05)$, as compared to the aged group II, and were measured as ( $10 \pm 0.7$ and $130.4 \pm 8.56$, Histogram 1). However, these values were significantly decreased $(P<0.05)$ as compared 
to the adult group. An apparent increase in mitral cell number was evident. They were apparently slightly larger than those of the aged group, however, not reaching the size of mitral cells of the adult group. Granule cell population was seen apparently increased as compared to the aged group, being comparable to the adult group denoting that apparent healing of the deeper parts of the OB preceded its superficial parts (Fig.5b).

Three days after intranasal ADSCs administration in group III, the olfactory bulb showed improvement of glomerular layer structure and in the juxtaglomerular cells' population (Fig.6a). No areas of lost glomeruli were detected; however, their size didn't return to the control appearance. This was confirmed by the statistical analysis, in which significantly increased glomerular number and size were detected $(P<0.05)$ as compared to group II and to the one-day time point of group III, measuring $(14.8 \pm 0.83,226.6 \pm 5$ Histogram 1). Meanwhile, mean glomerular number was non-significantly different $(P>0.05)$ from that of the adult group. However, mean glomerular size was significantly decreased $(P<0.05)$ as compared to the adult group. Mitral cells were apparently larger in size as compared to the aged group and to the one day time point of group III, and apparently smaller as compared to the adult group. Granule cell layer seemed comparable to the control adult group, and apparently didn't differ than that of the one day time point of group III (Fig. 6b).

Five days after intranasal ADSCs administration in aged rats of group III, the structure of olfactory bulb layers appeared nearly comparable to the adult group. No apparent change in glomerular number was seen as compared to the three days' time point of group III (Fig.7a). Mean number of glomeruli was counted as $(15.2 \pm 0.44)$ that was significantly increased $(P<0.05)$ as compared to group II and to the one-day time point of group III. However, it was non-significantly different $(P>0.05)$ when compared to the control adult group and to the three days' time point of group III (Histogram 1). Regarding the glomerular size, it was significantly increased $(P<0.05)$ as compared to those of group II and of the one and three days' time points of group III, measuring $(288 \pm 18.74)$. However, it was significantly decreased $(P<0.05)$ as compared to the adult control group (Histogram 1). Mitral and granule cells' population and structure were comparable to the control adult group (Fig. $7 b$ ).

Fourteen days after ADSCs intranasal administration in group III, reversal of the age-related structural changes was evident in all layers of the olfactory bulb (Figs. a, b). The number and size of glomeruli of the glomerular layer was seen comparable to the control adult group, as well as the juxtaglomerular cells' population (Fig.8a). The glomerular number was significantly increased $(P<0.05)$ as compared to the aged group (group II), and to the one-day time point of group III, counted as (15.4 \pm 0.54$)$. This value was non- significantly different $(P>0.05)$ as compared to the control adult group and to the three and five days' time point of group III (Histogram 1). The glomerular size reached the control values, being non-significantly $(P>0.05)$ different from it, measuring $(348.6 \pm 10.06)$ that was significantly increased $(P<0.05)$, as compared to the aged group and to all the previous time points of group III (Histogram 1). Mitral and granule cell layers were also comparable to those of the adult group (Fig.8b).

\section{3- Toluidine blue-stained sections}

Examination of the toluidine blue-stained sections of the control adult rats of group I revealed the presence of vast amount of cytoplasmic Nissl's granules in mitral cells (Fig.9). Mean Nissl's granules density measured (103.42 \pm 0.28 , mean \pm SD. Histogram 2).

Sections of the aged non-treated rats of group II revealed scanty Nissl's granule content in most of mitral cells (Fig.10). Mean Nissl's granules density measured $(89.93 \pm 1.31)$ that was significantly decreased $(P<0.05)$ as compared to the adult group (Histogram 2).

One day after intranasal ADSCs administration in group III, few Nissl's granules were noticed in focal areas of mitral cells' cytoplasm (Fig.11). Significant increase in mean Nissl's granules density was detected $(P<0.05)$ as compared to the aged group, measuring $(96.05 \pm 0.65)$. However, it was significantly decreased $(P<0.05)$ as compared to the adult group (Histogram 2).

Three days after intranasal ADSCs administration in aged rats of group III, moderate amount of Nissl's granules were noticed in some mitral cells' cytoplasm. Other mitral cells showed scanty Nissl's granules (Fig.12). Mean Nissl's granules density measured (98.68 \pm 0.74 ), that was significantly increased $(P<0.05)$ as compared to the aged group and to the one-day time point of group III. However, it was still significantly decreased $(P<0.05)$ when compared to the adult group (Histogram 2).

Five days after intranasal ADSCs administration in aged rats of group III, numerous cytoplasmic Nissl's granules were seen in most of the mitral cells (Fig.13). Mean Nissl's granules density measured $(102.33 \pm 0.21)$, that was significantly increased $(P<0.05)$ as compared to the aged group and to the one and three days' time points of group III. However, it was non-significantly decreased $(P>0.05)$ when compared to the adult group (Histogram 2).

Fourteen days after ADSCs intranasal administration in aged rats, toluidine blue-stained sections showed Nissl's granule amount in mitral cells comparable to the adult group (Fig. 14). Mean Nissl's granules density measured (103.28 \pm 0.33$)$, that was significantly increased $(P<0.05)$ as compared to the aged group and to the one and three 
days' time points of group III. However, it was nonsignificantly $(P>0.05)$ different from the adult group and non-significantly increased $(P>0.05)$ as compared to the five days' time point of group III (Histogram 2).

\section{4- Synaptophysin (SYP) immunohistochemically- stained sections:}

Examination of the glomeruli of SYP-stained sections of the control adult rats of group I showed strong positive immunoreactivity in all glomeruli. Moderate immunoreactivity was detected in the EPL (Fig.15). Mean density of glomerular SYP-immunoreactivity measured (97.87 \pm 0.66 , mean \pm SD, Histogram 3).

Synaptophysin immunohistochemically stained sections of the aged non-treated rats of group II revealed weak positive reaction in most of the glomeruli. Apparently decreased immunoreactivity of EPL was seen as compared to the adult group (Fig.16). Mean density of glomerular SYP-immunoreactivity measured $(60.74 \pm 0.6)$ that was significantly decreased $(P<0.05)$ as compared to the adult group (Histogram 3).

One day after intranasal ADSCs administration in group III, moderate SYP immunohistochemical reaction appeared in few glomeruli. However, other glomeruli exhibited weak reaction. Immunoreactivity of the EPL was apparently increased as compared to the aged non-treated group and was nearly comparable to the adult group (Fig.17). Mean density of glomerular SYP-immunoreactivity measured $(65.04 \pm 0.59)$ that was significantly increased $(P<0.05)$ as compared to the aged group. However, it was significantly decreased $(P<0.05)$ as compared to the adult group (Histogram 3).

Three days after intranasal ADSCs administration in group III, strong SYP immunoreactivity was observed in some glomeruli. Weak SYP immunoreactivity was observed in other glomeruli. The immunoreactivity of EPL was apparently increased as compared to the aged non-treated group and was nearly comparable to the adult group and to the one day time point of ADSCstreated group (Fig.18). Mean density of glomerular SYP-immunoreactivity measured $(70.39 \pm 0.87)$ that was significantly increased $(P<0.05)$ as compared to the aged group and to the one day time point of group III. However, it was still significantly decreased $(P<0.05)$ as compared to the adult group (Histogram 3).

Five days after intranasal ADSCs administration in aged rats of group III, strong SYP immunoreactivity was observed in most of the glomeruli. The immunoreactivity of EPL was apparently increased as compared to the aged non-treated group and was comparable to the adult group and to the one and three days' time points of ADSCstreated group (Fig. 19). Mean density of glomerular SYP-immunoreactivity measured $(78.33 \pm 0.59)$ that was significantly increased $(P<0.05)$ as compared to the aged group and to the one and three days' time points of group III. However, it was still significantly decreased $(P<0.05)$ as compared to the adult group (Histogram 3).

Fourteen days after ADSCs intranasal administration in aged rats, strong SYP immunoreactivity was observed in all glomeruli of the OB and of the EPL, appearing comparable to the adult group (Fig. 20). Mean density of SYP-immunoreactivity measured $(97.17 \pm 0.5)$ that was significantly increased $(P<0.05)$ as compared to the aged group and to all previous time points of group III. Meanwhile, it was non-significantly different $(P>0.05)$ as compared to the adult group (Histogram 3).

\section{5- S-100B immunohistochemically-stained sections}

Examination of the S-100B stained sections of the control adult rats of group I showed the presence of immunopositive mature astrocytes among juxtaglomerular cells (Fig. 21a), in EPL, among mitral and granule cells (Fig. 21b). Mean number of S-100B immunoreactive mature astrocytes was counted as $66.6 \pm 1.14$ (Histogram 3).

Immunohistochemical S-100B stained sections of the aged non-treated rats of group II revealed apparently large immunopositive mature astrocytes among juxtaglomerular cells as compared those of the adult group (Fig. 22a). Apparently large, numerous immunoreactive astrocytes were also noticed in the EPL and among mitral and granule cells (Fig. 22b). Mean number of S-100B-immunoreactive mature astrocytes was counted as $(247 \pm 2.54)$ that was significantly increased $(P<0.05)$ as compared to the adult group (Histogram 3).

One day after intranasal ADSCs administration in group III, apparent decrease in S-100B immunohistochemical reaction appeared among juxtaglomerular cells, in EPL (Fig.23a) and in-between mitral and granule cells (Fig. 23b). Mean number of S-100B-immunoreactive mature astrocytes was counted as $(101.8 \pm 0.83)$ that was significantly decreased $(P<0.05)$ as compared to the aged group. However, it was significantly increased $(P<0.05)$ as compared to the adult group (Histogram 3).

Three days after intranasal ADSCs administration in aged rats of group III, some S-100B immunoreactive mature astrocytes were observed among juxtaglomerular cells (Fig. 24a), in EPL and in-between mitral and granule cells (Fig. 24b). Mean number of S-100B-immunoreactive mature astrocytes was counted as $(65.2 \pm 1.48)$ that was significantly decreased $(P<0.05)$ as compared to the aged group and to the one day time point of intranasal ADSCs administration in group III. However, it was nonsignificantly decreased $(P>0.05)$ as compared to the adult 
group (Histogram 3).

Five days after intranasal ADSCs administration in aged rats of group III, few S-100B immunoreactive mature astrocytes were seen in all layers of OB (Fig. 25 a, b). Mean number of S-100B-immunoreactive mature astrocytes was counted as $(27.4 \pm 1.14)$ that was significantly decreased $(P<0.05)$ as compared to groups I and II, and to the one and three days' time points of group III (Histogram 3).
Fourteen days after ADSCs intranasal administration in aged rats, minimal S-100B immunoreactive mature astrocytes was seen in all layers of $\mathrm{OB}$, and was nearly comparable to the adult group and to the five days' time point of group III (Fig. $25 \mathrm{a}, \mathrm{b}$ ). Mean number of S-100B-immunoreactive mature astrocytes was counted as $(29 \pm 0.7)$ that was significantly decreased $(P<0.05)$ as compared to the adult and aged groups and to the one and three days' time points of group III. In addition, it was nonsignificantly different $(P>0.05)$ as compared to the five days' time point of group III (Histogram 3).

Histogram 1: Mean number (a) and size in $\mu \mathrm{m}$ (b) of glomeruli in different groups
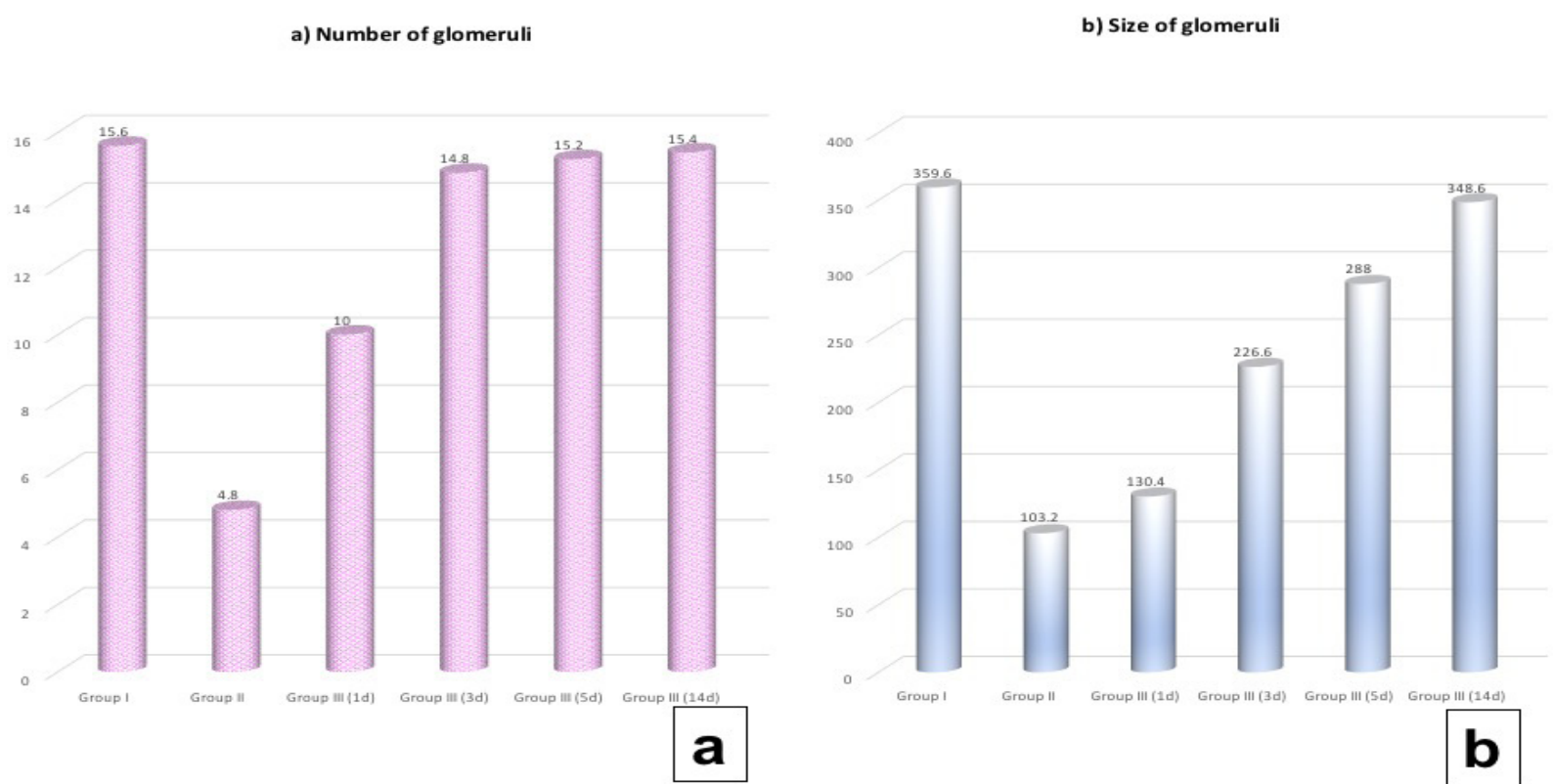

Histogram 2: Mean of Nissl's granules density in mitral cells in different groups

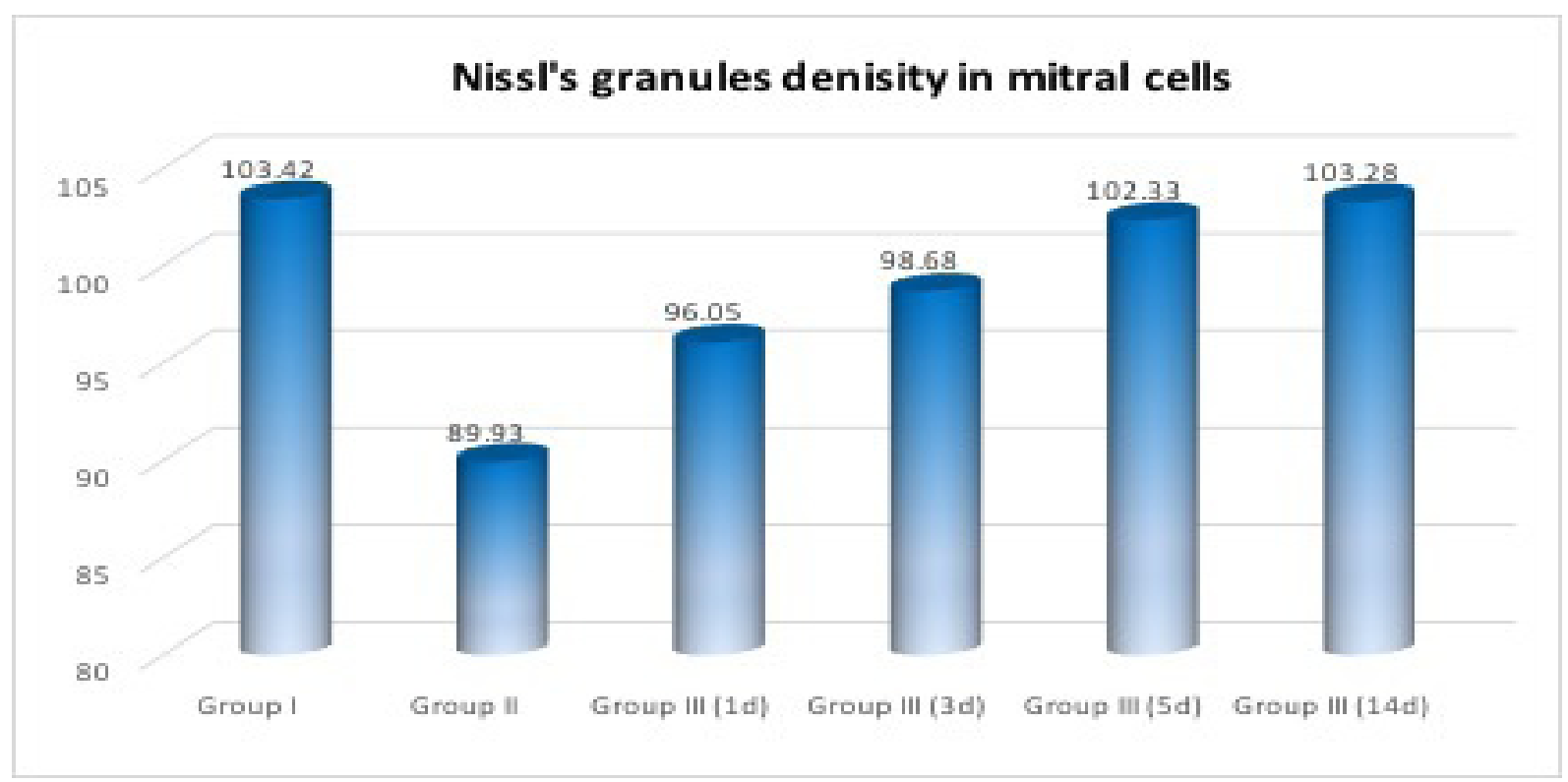


Histogram 3: Mean density of glomerular synaptophysin (a) and mean number of S100B (b) immunoreactivity in different groups
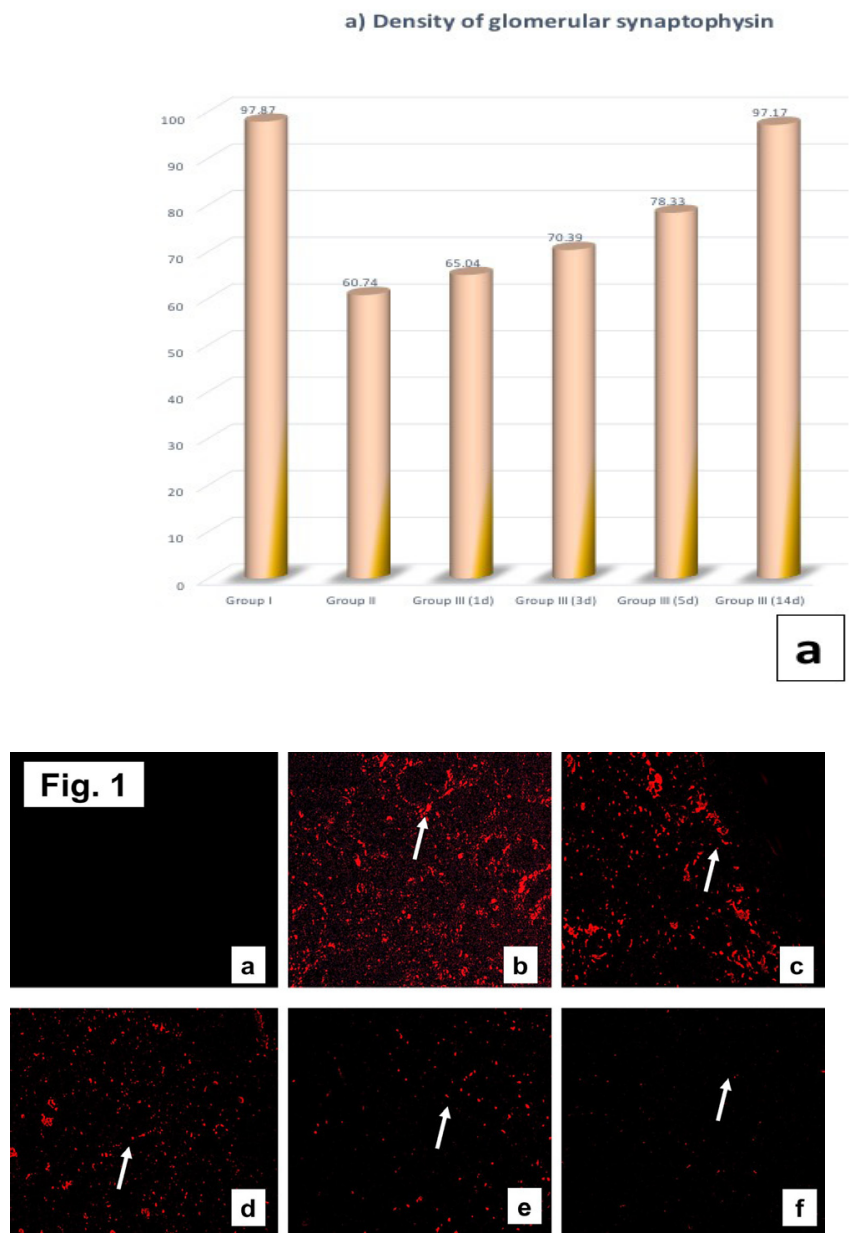

Fig. 1: Showing (a): No fluorescence in the aged non-treated section. (b): Maximum fluorescence in all layers of $\mathrm{OB}$ after two hours of PKH26-labelled ADSCs intranasal administration $(\uparrow)$. Gradual decrease in ADSCs fluorescence $(\uparrow)$ is noticed after one (C), three (d), five (e) and 14 days (f) of ADSCS intranasal administration.

Inverted fluorescent microscope $\mathrm{x} 200$

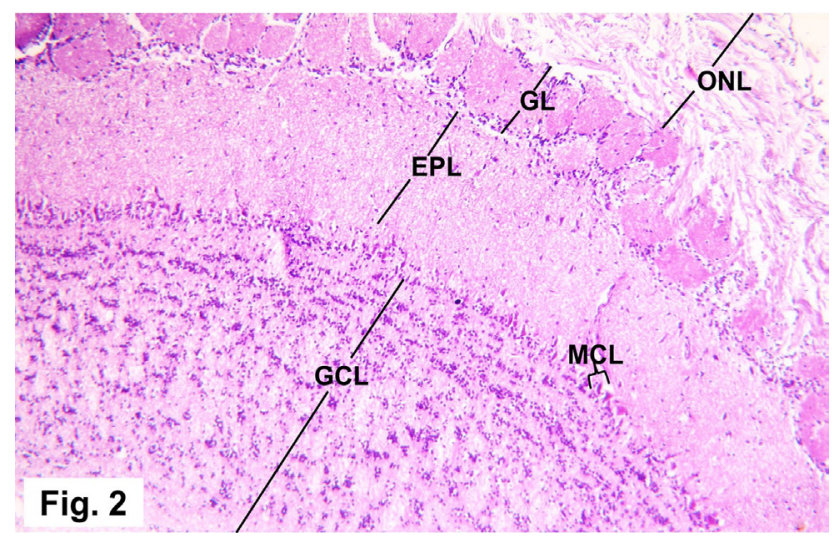

Fig. 2: Adult group showing olfactory bulb structure composed of olfactory nerve fibers layer (ONL), glomerular layer (GL), external plexiform layer (EPL), mitral cell layer (MCL) and granule cell layer (GCL).

H\&E x 100 b) Number of $\mathrm{S} 100$ positive cells
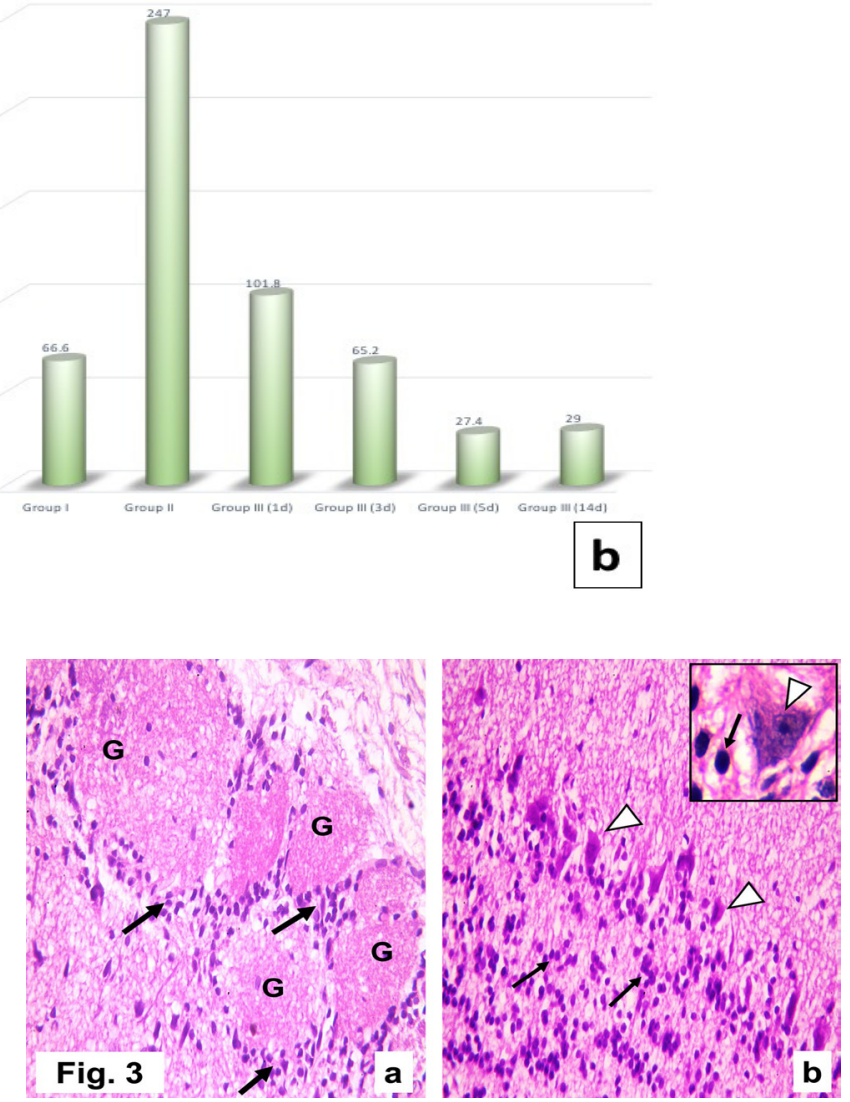

Fig.3: Adult group showing (a): Glomeruli (G) consisting of acellular synaptic nearly spherical masses, surrounded by small juxtaglomerular cells $(\uparrow)$. (b): A row of large mitral cells $(\Delta)$, closely related to granule cells $(\uparrow)$. Inset shows a high magnification of mitral cell appearing triangular with acidophilic cytoplasm containing basophilic patches and large rounded vesicular nucleus $(\Delta)$. Notice the small granule cell with deeply stained rounded nucleus and thin rim of cytoplasm $(\uparrow)$.

H\&E x 400, inset x 1000

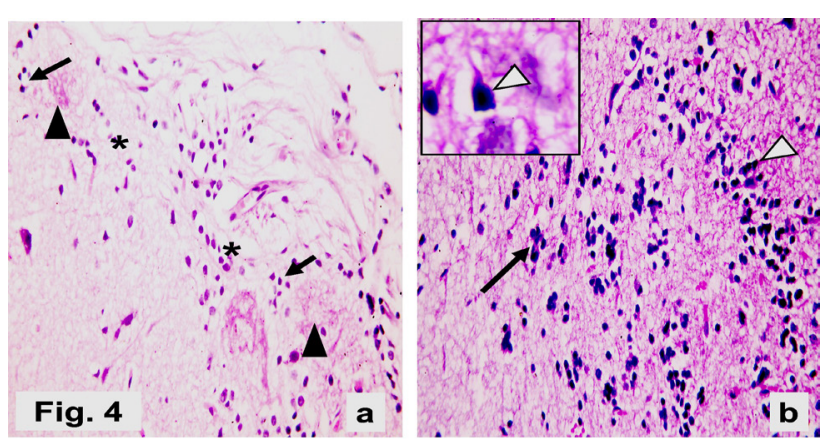

Fig. 4: Aged non-treated group showing (a): Glomerular layer appears with areas devoid of glomeruli $(*)$. The remaining glomeruli appear small in size $(\boldsymbol{\Lambda})$, and surrounded by few juxtaglomerular cells $(\uparrow)$. (b and inset): Few small deeply stained mitral cells $(\Delta)$, and few granule cells $(\uparrow)$ can be noticed in the GCL.

H\&E x 400, inset x 1000 


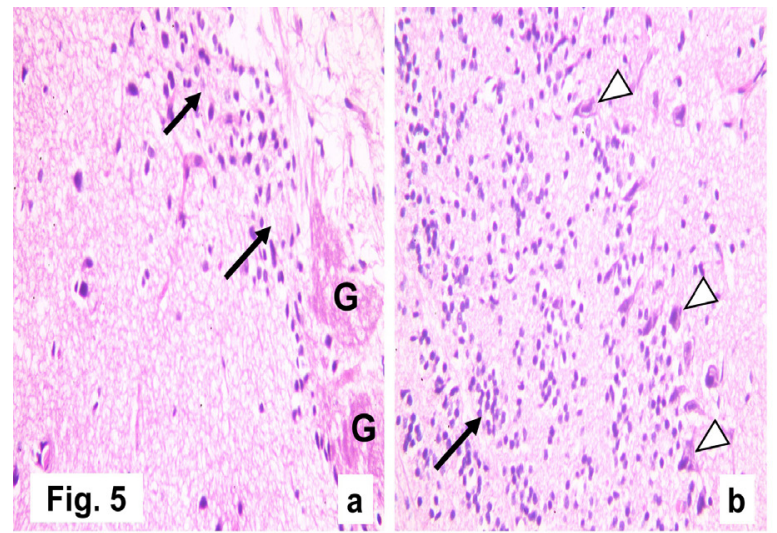

Fig. 5: One day after intranasal ADSCs administration in group III, showing (a): Widely spaced glomeruli are seen (G). Notice the juxtaglomerular cells $(\uparrow)$. (b): small mitral cells $(\Delta)$, and numerous granule cells $(\uparrow)$ are noticed.

$\mathrm{H} \& \mathrm{E}$ x 400

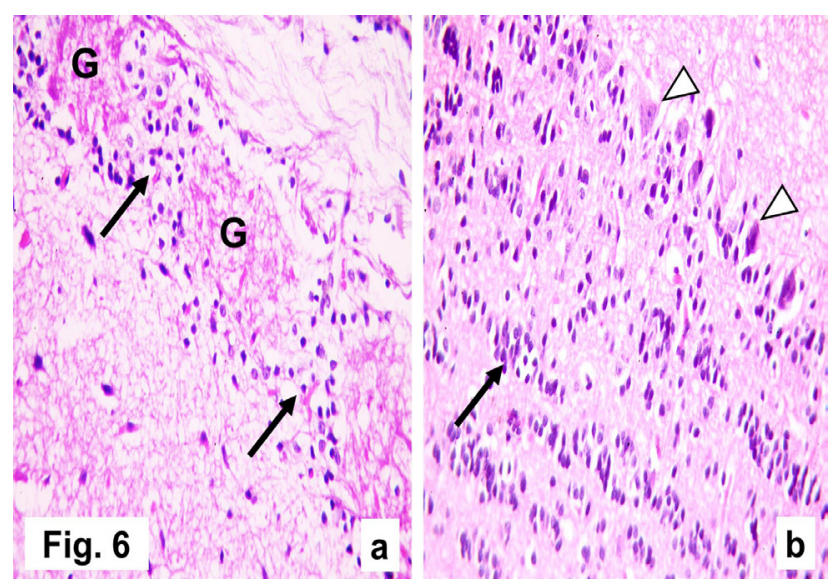

Fig. 6: Three days after intranasal ADSCs administration in group III, showing (a): numerous glomeruli (G) are seen surrounded by numerous juxtaglomerular cells $(\uparrow)$. (b): Medium-sized mitral cells are seen $(\Delta)$, together with numerous granule cells $(\uparrow)$.

H\&E x 400

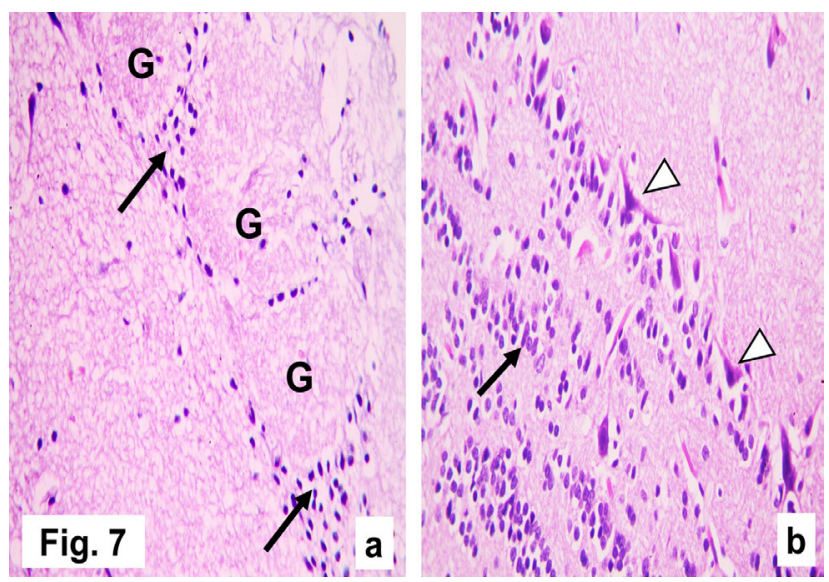

Fig. 7: Five days after intranasal ADSCs administration in group III, showing (a): numerous closely packed glomeruli can be seen $(\mathrm{G})$, with juxtaglomerular cells in-between $(\uparrow)$. (b): medium sized mitral cells $(\Delta)$, and numerous granule cells $(\uparrow)$ can be seen.

$\mathrm{H} \& \mathrm{E}$ x 400

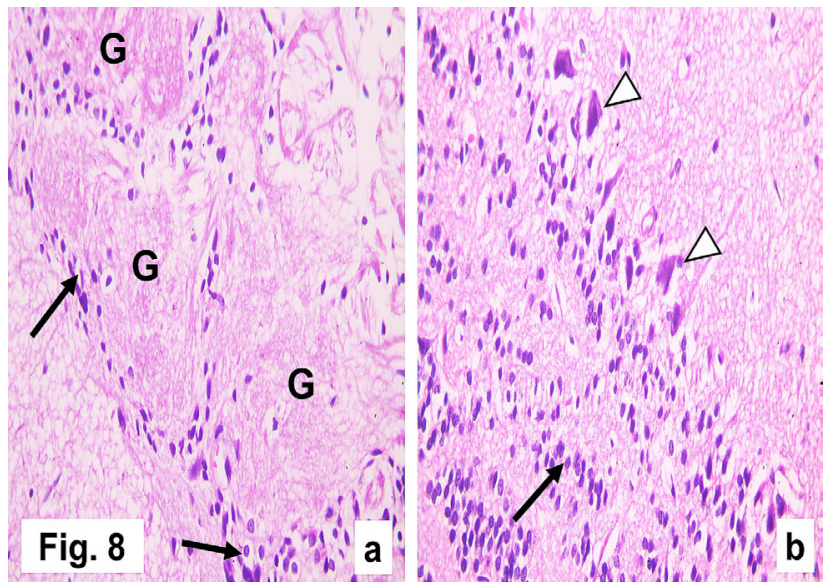

Fig. 8: Fourteen days after intranasal ADSCs administration in group III, showing (a): closely packed large glomeruli (G) surrounded by numerous juxtaglomerular cells ( $\uparrow)$. (b): Large mitral cells $(\Delta)$, and numerous granule cells $(\uparrow)$ can be noticed.

$\mathrm{H} \& \mathrm{E} \times 400$

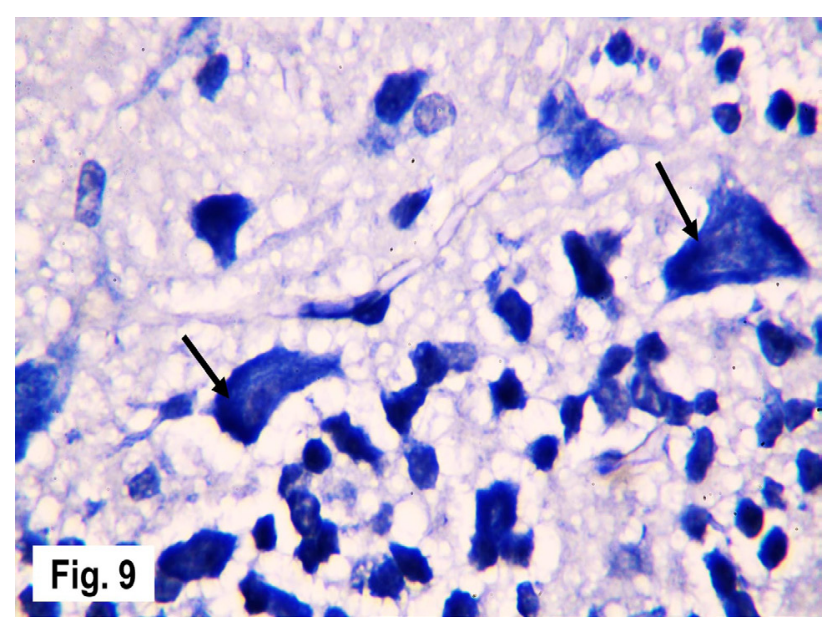

Fig. 9: Adult group showing numerous Nissl's granules in the cytoplasm of mitral cells $(\uparrow)$.

Toluidine blue $\mathrm{x} 1000$

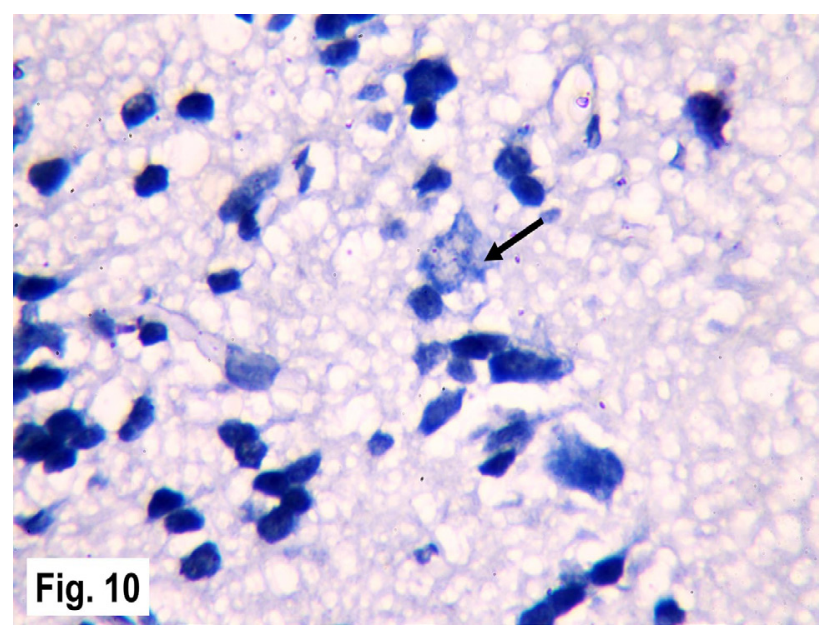

Fig. 10: Aged non-treated group showing scanty Nissl's granules in mitral cells' cytoplasm $(\uparrow)$.

Toluidine blue x 1000 


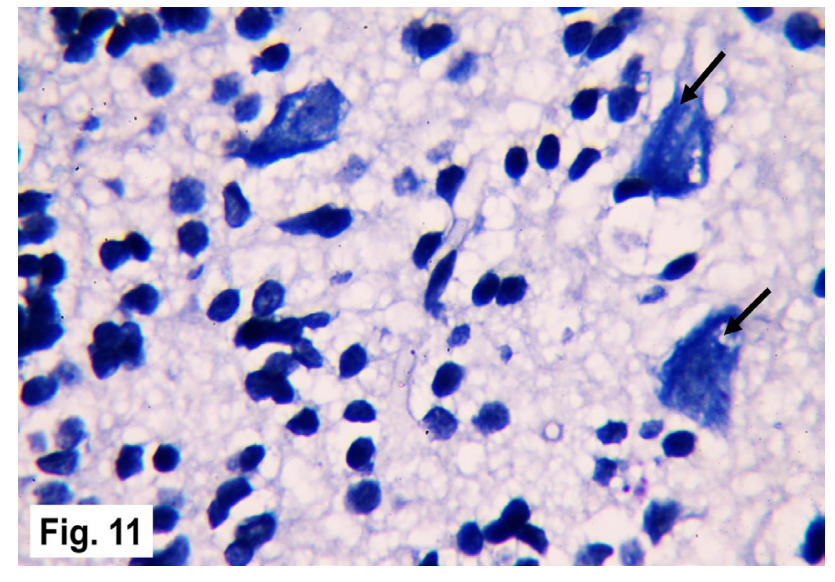

Fig. 11: One day after intranasal ADSCs administration in group III, showing little amount Nissl's granules in mitral cells' cytoplasm ( $\uparrow$.

Toluidine blue x 1000

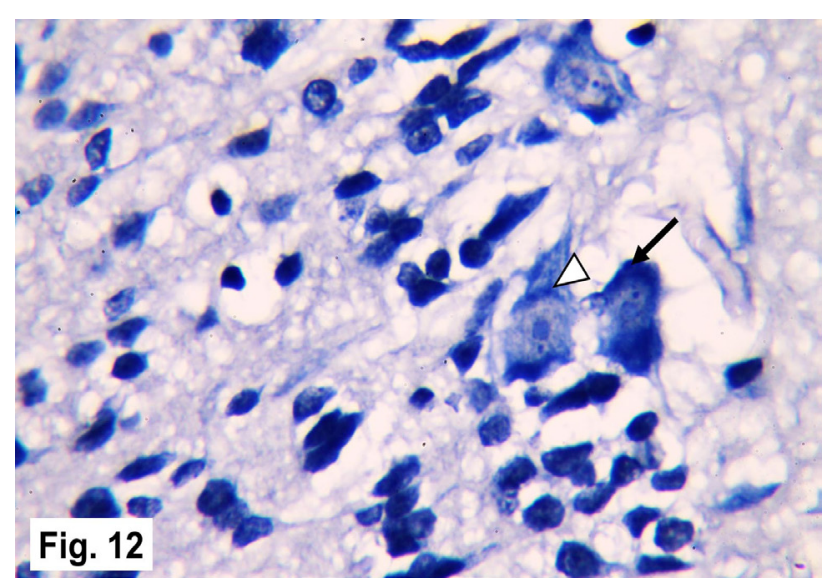

Fig. 12: Three days after intranasal ADSCs administration in group III, showing moderate amount of Nissl's granules in the cytoplasm of some mitral cells $(\uparrow)$ and few Nissl's granule in others $(\Delta)$.

Toluidine blue $\mathrm{x} 1000$

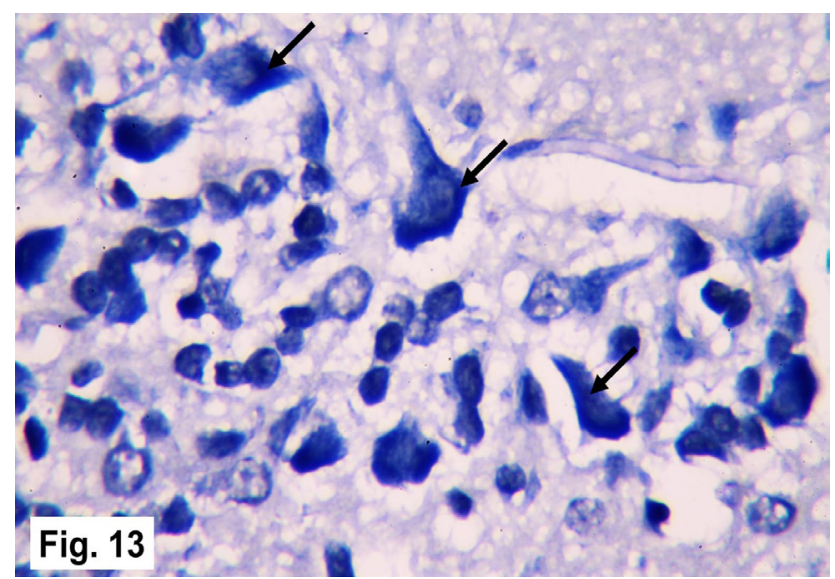

Fig. 13: Five day after intranasal ADSCs administration in group III, showing numerous Nissl's granules in mitral cells' cytoplasm $(\uparrow)$.

Toluidine blue x 1000

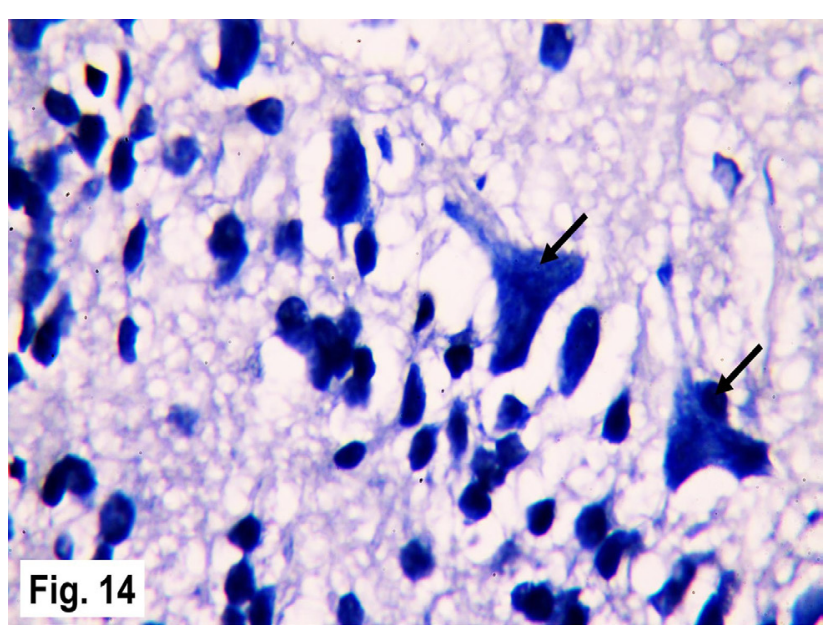

Fig. 14: Fourteen days after intranasal ADSCs administration in group III, showing the cytoplasm of mitral cells studded with Nissl's granules $(\uparrow)$.

Toluidine blue x 1000

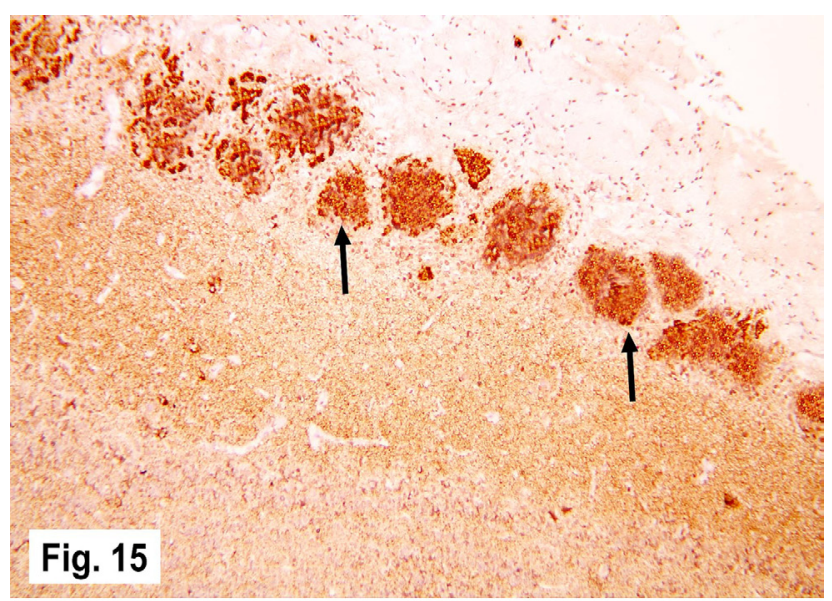

Fig. 15: Adult group showing strong synaptophysin (SYP) immunoreactivity $(\uparrow)$ in the glomeruli of olfactory bulb.

Avidine biotin peroxidase technique $\mathrm{x} 100$

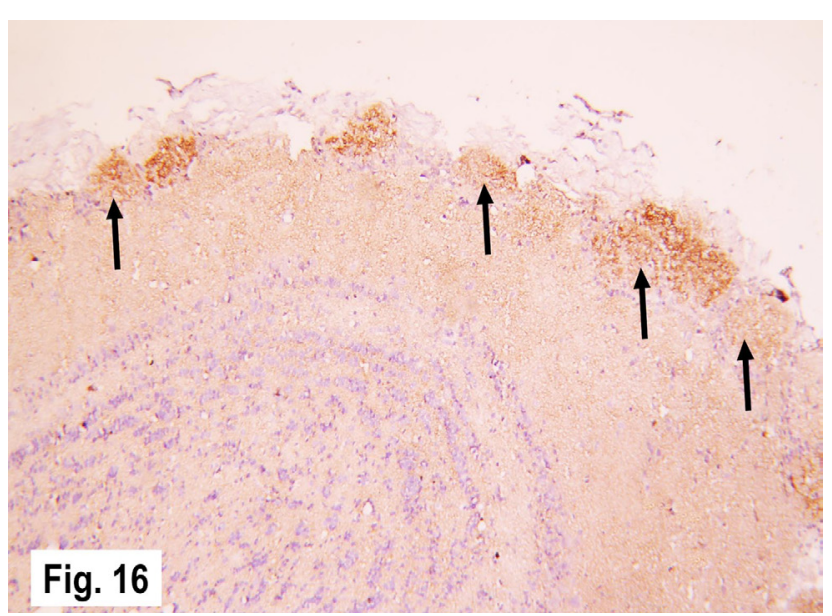

Fig. 16: Aged non-treated group showing weak SYP immunoreactivity $(\uparrow)$ in most of olfactory bulb glomeruli.

Avidine biotin peroxidase technique $\mathrm{x} 100$ 


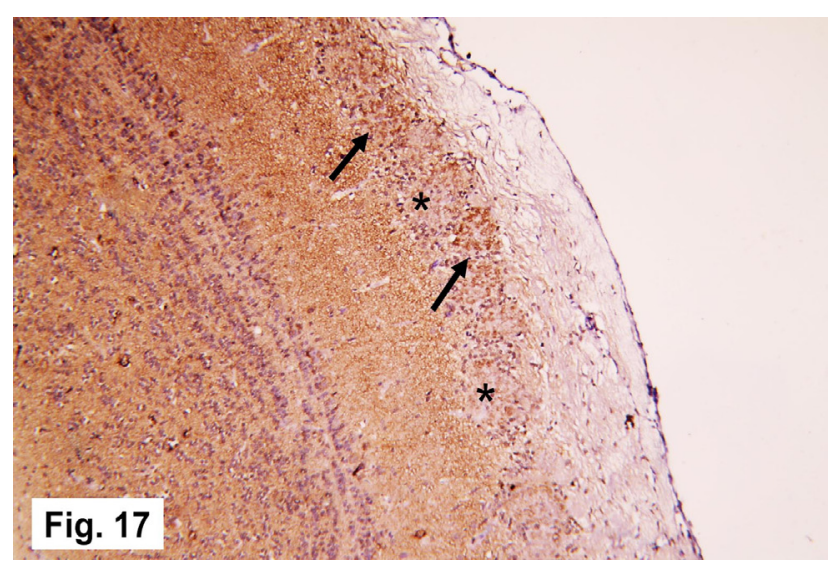

Fig. 17: One day after intranasal ADSCs administration in group III, showing moderate SYP immunoreactivity ( $\uparrow$ ) in few glomeruli and weak immunoreaction in others $(*)$.

Avidine biotin peroxidase technique x 100

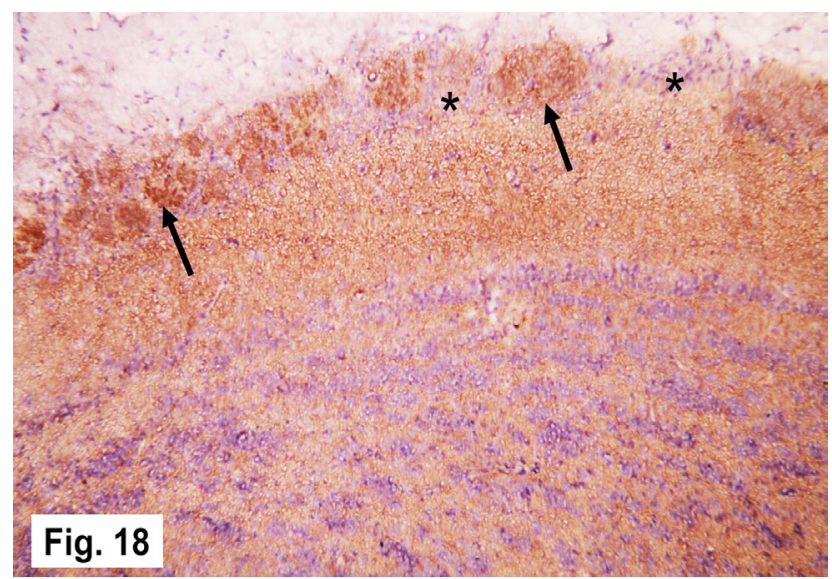

Fig. 18: Three days after intranasal ADSCs administration in group III, showing strong SYP immunoreactivity $(\uparrow)$ in some glomeruli of olfactory bulb. Notice the weak immunoreactivity in other glomeruli (*).

Avidine biotin peroxidase technique $\mathrm{x} 100$

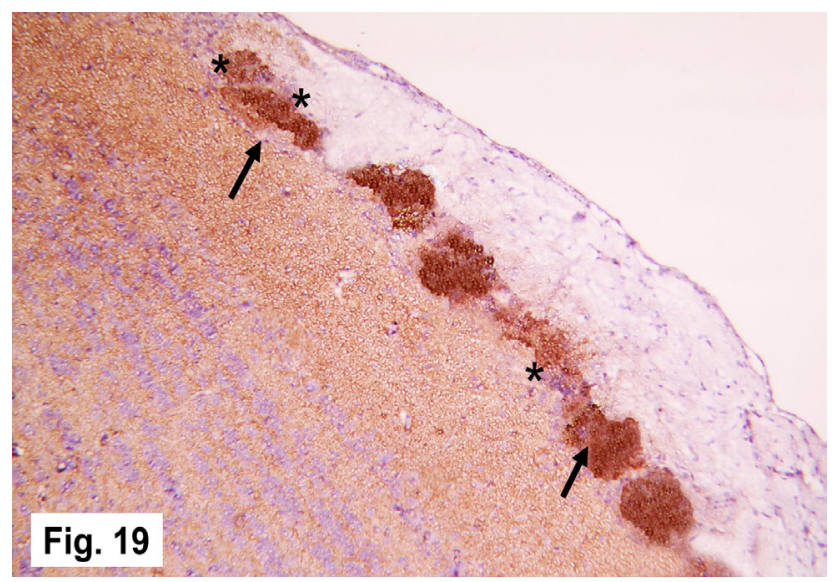

Fig. 19: Five days after intranasal ADSCs administration in group III, showing strong SYP immunoreactivity $(\uparrow)$ in most of the glomeruli. However, moderate immunoreactivity can be noticed in others $(*)$.

Avidine biotin peroxidase technique $\mathrm{x} 100$

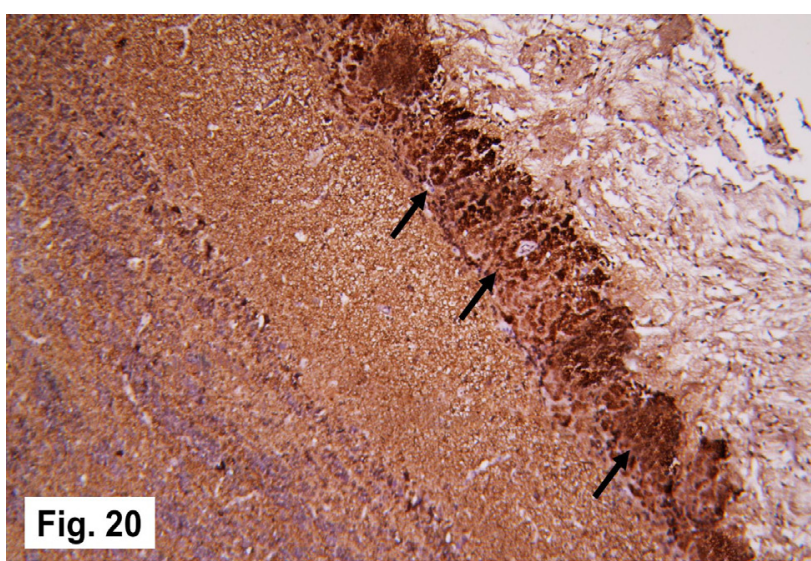

Fig. 20: Fourteen days after intranasal ADSCs administration in group III, showing strong SYP immunoreactivity $(\uparrow)$ in all glomeruli of olfactory bulb.

Avidine biotin peroxidase technique x 100

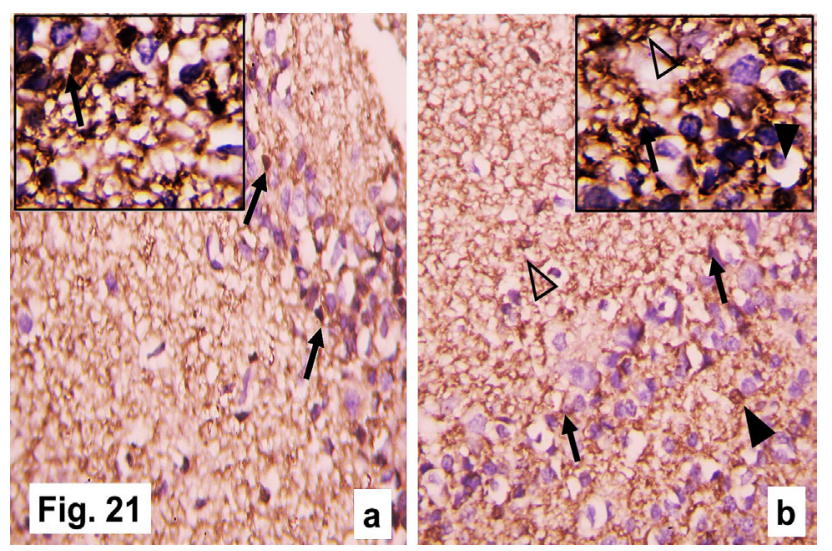

Fig. 21: Adult group showing (a, inset): S-100B immunoreactive mature astrocytes extending short cytoplasmic processes inbetween juxtaglomerular cells $(\uparrow)$. (b, inset): Immunoreactive mature astrocytes can be seen in the $\operatorname{EPL}(\Delta)$, in-between mitral $(\uparrow)$ and granule cells $(\boldsymbol{\Lambda})$.

Avidine biotin peroxidase technique $\mathrm{x} 400$, inset x 1000

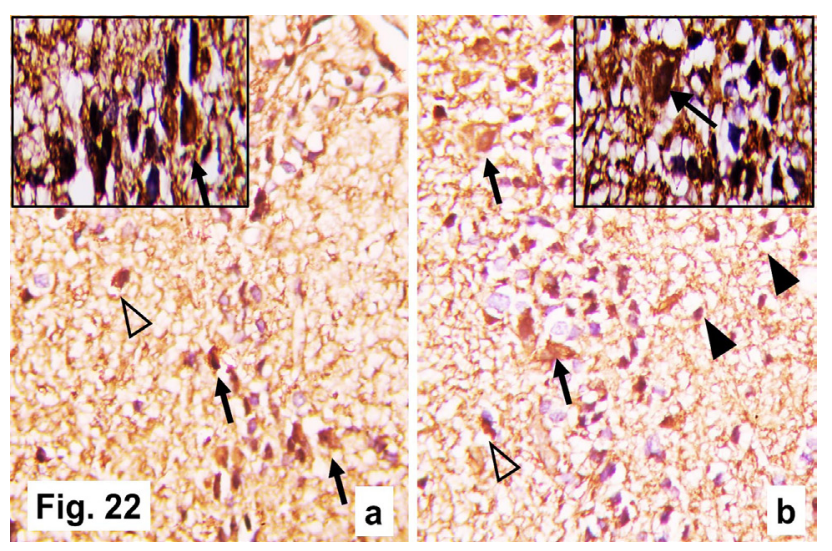

Fig.22: Aged group showing ( $a$, inset): Some S-100B immunoreactive mature astrocytes in-between juxtaglomerular cells $(\uparrow)$ and in the $\operatorname{EPL}(\Delta)$. (b, inset): Numerous immunoreactive mature astrocytes can be seen in the EPL $(\Delta)$, in-between mitral $(\uparrow)$ and granule cells $(\boldsymbol{\Delta})$.

Avidine biotin peroxidase technique x 400, inset x 1000 


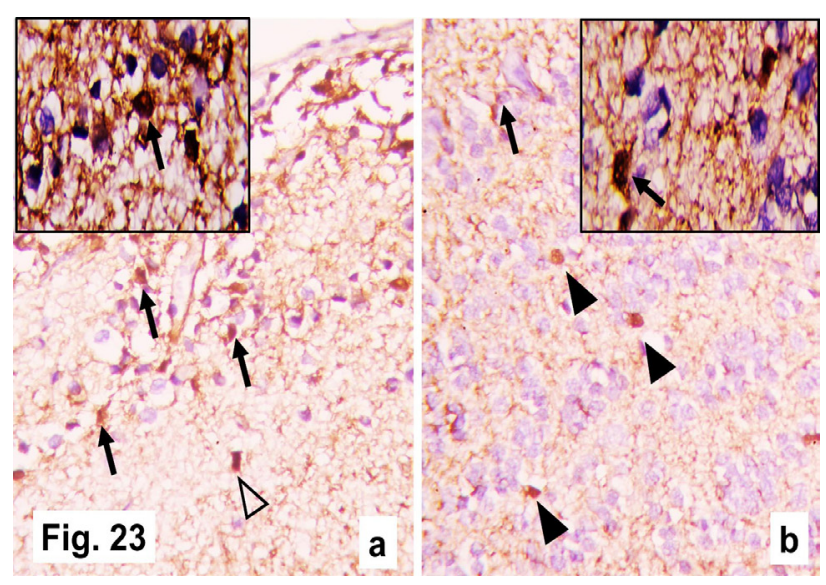

Fig. 23: One day after intranasal ADSCs administration in group III, showing (a, inset): Some S-100B immunoreactive mature astrocytes in-between juxtaglomerular cells $(\uparrow)$ and in the EPL $(\Delta)$. (b, inset): Some immunoreactive mature astrocytes can be also seen in-between mitral $(\uparrow)$ and granule cells $(\boldsymbol{\Delta})$.

Avidine biotin peroxidase technique x 400, inset x 1000
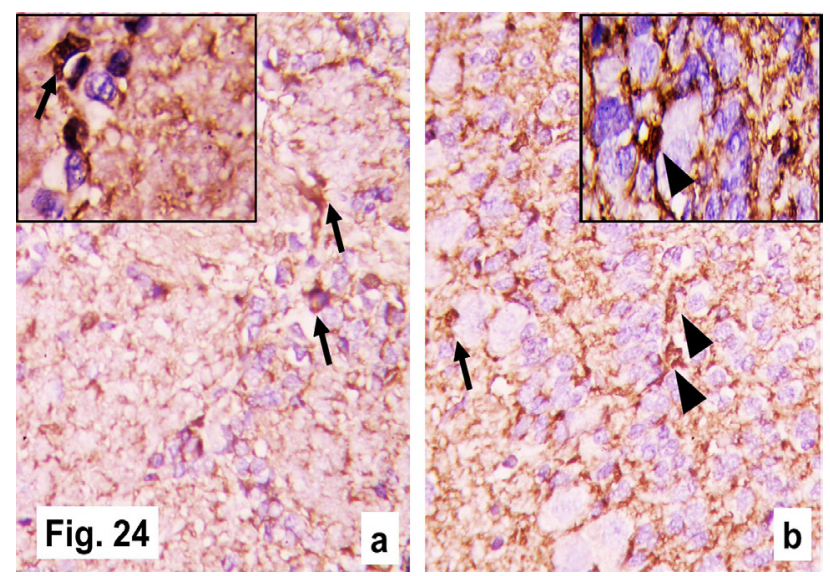

Fig. 24: Three days after intranasal ADSCs administration in group III, showing (a, inset): Some S-100B immunoreactive mature astrocytes in-between juxtaglomerular cells $(\uparrow)$. (b, inset): Some immunoreactive mature astrocytes are noticed among mitral $(\uparrow)$ and granule cells $(\boldsymbol{\Delta})$.

Avidine biotin peroxidase technique x 400, inset x 1000

\section{DISCUSSION}

Since no apparent sex differences in the structure of human olfactory bulbs were reported, we conducted the current research on female rats ${ }^{[2,16]}$. Interestingly, it was demonstrated recently that gonadectomized female mice exhibited slower responses to odorants in fewer glomeruli than adult female mice. Meanwhile, in gonadectomized males, this sex difference was reversed so that they exhibited faster response in more glomeruli than control adult male mice ${ }^{[17]}$.

The laminar organization of the olfactory bulb (OB) combines a unique neuronal morphology and complex synaptic connections. The glomeruli of $\mathrm{OB}$ act as first synaptic relay of the olfactory pathway. They receive
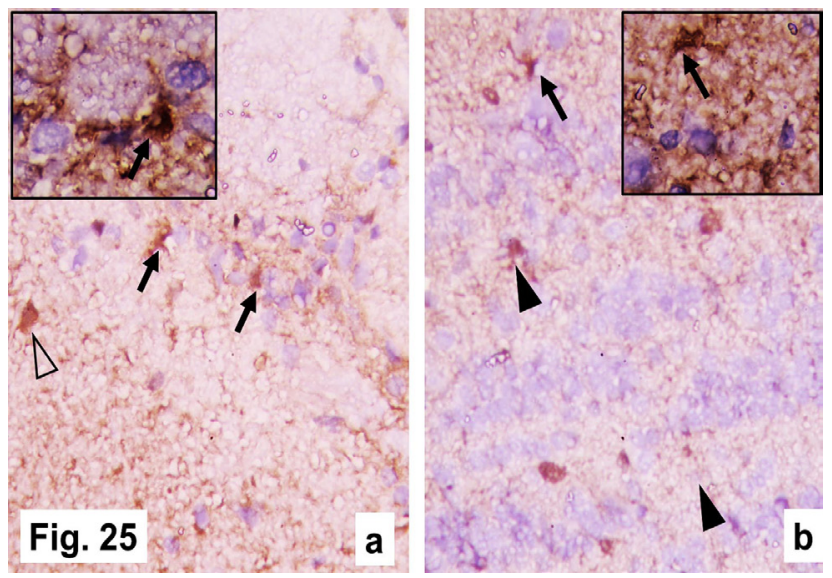

Fig. 25: Five days after intranasal ADSCs administration in group III, showing (a, inset): Few S-100B immunoreactive mature astrocytes in-between juxtaglomerular cells $(\uparrow)$ and in the EPL $(\Delta)$. (b, inset): Few immunoreactive mature astrocytes can be also noticed among mitral $(\uparrow)$ and granule cells $(\boldsymbol{\Delta})$.

Avidine biotin peroxidase technique x 400, inset x 1000

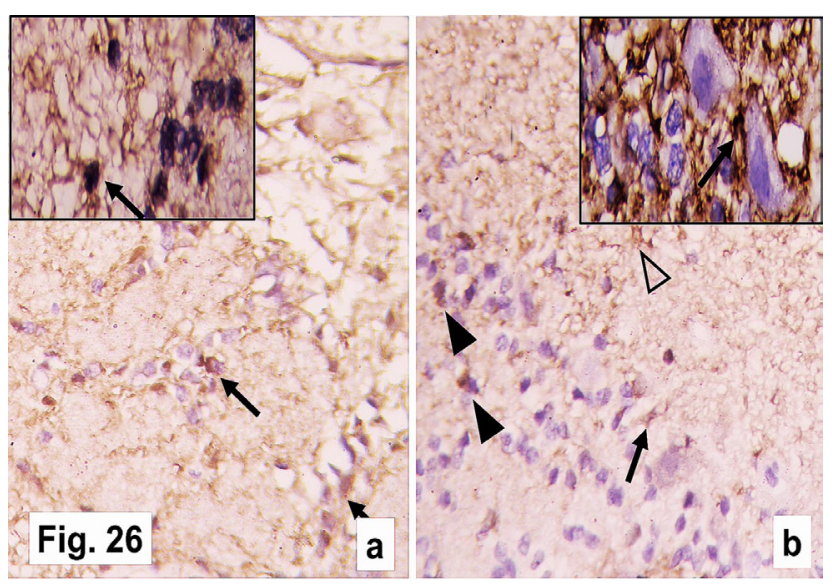

Fig. 26: Fourteen days after intranasal ADSCs administration in group III, showing (a, inset): Minimal S-100B immunoreactivity in-between juxtaglomerular cells $(\uparrow)$. (b, inset): Minimal immunoreactivity can be also seen in the EPL $(\Delta)$, among mitral $(\uparrow)$ and granule cells $(\boldsymbol{\Delta})$.

Avidine biotin peroxidase technique x 400, inset x 1000

afferent input from olfactory sensory neurons (OSNs) of olfactory epithelium. These axons make axodendritic synapses with the primary dendrites of mitral and tufted cells of OB in the glomerular neuropil, while the axons of mitral cells project to the olfactory cortex. Local synaptic circuit also exist in the glomeruli consisting of dendrodendritic synapses between dendrites of juxtaglomerular cells and those of mitral and tufted cells ${ }^{[18]}$. Thus, these unique structures play a basic role in smell perception and modify the response of the output neurons for sharp tuning of a given odor ${ }^{[19]}$. Subsequently, the glomeruli and mitral cells are considered the main integrative and relay elements of the $\mathrm{OB}^{[5]}$.

In the current study, $\mathrm{OB}$ of aged non-treated rats exhibited marked degenerative structural changes. 
Significant decrease in number and size of glomeruli with apparent decrease in population of juxtaglomerular, mitral and granule cells were demonstrated. This was accompanied by a subsequent significant decrease in Nissl's granules of mitral cells. This was in accordance with previous investigations that reported decline of the glomeruli and mitral cells population at an approximate rate of about $10 \%$ per decade. The researchers added that only $25 \%$ of glomeruli remained intact ${ }^{[16]}$.

The decline in cells' population was attributed in previous investigation to the aging-related degeneration of OSNs that might lead to decrease or even loss of neurotrophic factors synthesis, and consequently, to reduction in number and size of the glomeruli and the related mitral cells of OB. Most of OSN degeneration might be secondary to damage to the olfactory neuroepithelium caused by nasal infections, chronic rhinitis, changes in mucous production in elderly. Moreover, age-dependent increase in the quiescent pool of basal stem cells of olfactory epithelium with an accompanying decrease in the number of OSNs could also account for olfactory dysfunction in elderly ${ }^{[2]}$. It has been postulated that number of glomeruli of $\mathrm{OB}$ could be indeed a relevant indicator of olfactory epithelium destruction ${ }^{[16]}$. Sleep apnea associated with restriction of nasal airflow has been also recently implicated in olfactory dysfunction in aged individuals $^{[20]}$. Moreover, many age-related neurodegenerative diseases have been associated with olfactory dysfunction in elderly, suggesting that some age-related alterations of $\mathrm{OB}$ may reflect pre-clinical neurodegenerative diseases as Alzheimer's disease ${ }^{[21]}$ parkinson's disease $^{[22]}$ and schizophrenia ${ }^{[23]}$.

Most importantly, although postnatal continuous turnoverofOBneurons was documented ${ }^{[24]}$, cell proliferation and neurogenesis was documented to be decreased in the subventricular zone (SVZ) during aging ${ }^{[24]}$. Atrophy was reported to occur within the SVZ niche, together with stenosis of the ventral wall of the lateral ventricle, thus restricting neurogenesis to the dorsolateral region of the lateral ventricle ${ }^{[25]}$. This would result in fewer new adultborn neuroblasts reaching the olfactory bulb through the rostral migratory stream. Hence less differentiation into interneurons occurs with aging ${ }^{[2]}$. These neuroblasts are now known to continuously differentiate into either granule cells $(95 \%)$-mainly incorporating into the deeper part of GCL- or periglomerular cells $(5 \%)^{[26]}$. Thus, the consequent decrease in population of $\mathrm{OB}$ interneurons during aging would be the end result consistent with our results where a decreased juxtaglomerular and granule cell population was detected, with a more obvious decrease in the granule cells in the deep part of GCL. In context, OB local interneurons modulate the activity of mitral/tufted cells, contributing to odor signal integration ${ }^{[27]}$. This could explain the decreased population of mitral cells seen in the aged non-treated group of the present study.
In the current work, examination of synaptophysin (SYP) immunohistochemically-stained sections, synaptic connections of the OB were seen in condensed mainly in the glomeruli, and to a lesser extent in the EPL. In this view, SYP is known to be a transmembrane glycoprotein found in presynaptic vesicles involved in the packaging, storage, release of neurotransmitters, and it is reported to be prominent in olfactory bulb glomeruli. It was demonstrated that the glomerular neuropil contains the axodendritic synapses between the terminal arborizations of OSNs and the apical dendrites of mitral, tufted, and juxtaglomerular cells. A local circuit of dendrodendritic synapses also exists between mitral/tufted cell dendrites and the juxtaglomerular cell dendrites in the glomeruli. Of note, each glomerulus was documented to be molecularly specific in that it receives afferent input from OSNs expressing the same odorant receptors ${ }^{[2]}$. The findings of the current study revealed a significant decrease in SYP immunoreactivity in the aged non-treated group. In agreement, both axodendritic and dendrodendritic synapse densities were demonstrated to be decreased with aging.

By contrast, the dendrodendritic synapses density in the EPL was stable ${ }^{[28]}$. This finding might reflect the decrease in OSNs innervating the glomeruli, as well as the age-dependent decrease in the dendritic arbors of the juxtaglomerular cells as previously reported. These authors added that the aging most immediate effect occurred at the first synaptic relay in the glomeruli, with a preservation of downstream circuitry in the $\mathrm{OB}^{[2]}$.

By contrast to the decreased neurons' population in the aged non-treated group of the present work, a significant increase in mature astrocytes' number was detected by S100B immunohistochemical staining. Going with this result, it was previously suggested that decreased neuronal elements was usually accompanied by increases in astrocytes number ${ }^{[29]}$. This could compensate for a reduction in the glomerular space occupied by axons and dendrites ${ }^{[28]}$. In addition, mature reactive astrocytes have been reported to induce astrogliosis and impaired neuronal regeneration $^{[30,31]}$.

In a trial of reversing the aging-induced structural degeneration of $\mathrm{OB}$, allogenic ADSCs were used in this work in group III. Previous studies determined that ADSCs were not immunogenic and didn't elicit an immune response attributed to the reduced expression of surface histocompatibility antigens of human passaged ADSCs that could no longer stimulate a mixed lymphocyte reaction ${ }^{[32]}$. Moreover, ADSCs were reported to suppress immunoreactions ${ }^{[33]}$, and might not elicit a cytotoxic T-cell response in vivo ${ }^{[34]}$.

The intranasal route of ADSCs delivery to the aged OB was used in the current work. It is -by far- the first time that this approach of treatment had been investigated in such 
case. The intranasal route has been recently investigated as a novel delivery route of drugs ${ }^{[35]}$, neurotrophic factors ${ }^{[36]}$ and stem cells to the brain ${ }^{[14,37]}$. This approach avoided the side effects detected after systemic administration such as pulmonary embolism, infarctions and obstruction by the $\mathrm{BBB}^{[37]}$. Mesenchymal stem cells delivered into the nasal cavity have been shown to migrate through the cribriform plate and into brain tissue through the olfactory and trigeminal pathways ${ }^{[14]}$.

Tracking of the delivered PKH26-labelled ADSCs was done by detecting their positive fluorescence by the fluorescent microscope. The presence of these cells was maximum two hours after their intranasal administration and gradually decreased with advancing time denoting the stem cells might have been differentiated into neuronal cells. This agreed with other authors who documented that MSCs migrate from the nasal cavities to the forebrain within two hours after administration and the number decreases sharply at three days ${ }^{[38]}$. This might be supported by the results of a recent study that reported the pluripotent ability of ADSCs to differentiate into neuronal cells ${ }^{[39]}$.

In this regard, gradual improvement of the histological structure of the OB has been detected after different time points of ADSCS treatment in group III of the present study. This improvement was noted from day one after treatment and progressed through the three and five days after treatment, reaching its ultimate therapeutic effect on $\mathrm{OB}$ structure after 14 days of administration. Going with these results, it has been previously documented that ADSCs could differentiate into neuronal or neuronal precursor cells, both morphologically and functionally ${ }^{[40]}$. In addition, ADSCs treatment reduced the brain atrophy and glial hypertrophy in a hemorrhagic stroke model ${ }^{[41]}$. The MSCs were reported to migrate to a spinal cord injury where they partially differentiated into neurons and oligodendrocytes, and restored locomotor functions ${ }^{[42]}$. Moreover, newly born cells were found to be initially integrated into the deeper parts of GCL ${ }^{[24]}$. This was in accordance with the results of the present study that showed restored deeper granule cells' population after one day intranasal ADSCs administration in group III. Meanwhile, restoration of more superficial parts as glomerular layer including the juxtaglomerular cells was obvious at day three after treatment.

Until recently, the mitral cells of the OB were thought to be born exclusively during early embryogenesis ${ }^{[43]}$. However, recent research showed that numerous migrating dorsal SVZ-derived neuroblasts expressed transcription factors restricted to the mitral glutamatergic neurons and concluded that these cells of $\mathrm{OB}$ are produced throughout adult life $\mathrm{e}^{[44]}$. Noteworthy, OB local interneurons were also found to modulate the activity of mitral/tufted cells ${ }^{[27]}$. The results of all these investigations support our findings where apparent increase in mitral cells' number was observed in group III after ADSCs administration. Taken together, increased neuronal population of $\mathrm{OB}$ in all layers could be the direct cause of increased synaptic circuits seen by SYP immunostaining after ADSCS treatment in group III of the present work.

A number of nonexclusive mechanisms through, which ADSCs could repair and regenerate tissue, has been postulated, other than their differentiation into a desired lineage. The ADSCs might secrete growth factors and cytokines that act in a paracrine manner to stimulate recovery. A previous study suggested that intranasal MSCs might induce neurotrophic factors production through paracrine signaling, which in turn could promote differentiation of precursor cells towards neuroblasts in the SVZ niche ${ }^{[45]}$. In addition, they might stimulate recruitment of the endogenous stem cells residing in the stem cell niche to the affected site, and promote their differentiation. In addition, they might produce antioxidants and free radical scavengers in the local environment thus removing the toxic substances and promote recovery of surviving cells $^{[46]}$.

Synaptic connections were apparently gradually established after ADSCs treatment in group III of the current work. This was detected by significantly increased SYP-immunoreactivity mainly in glomeruli and EPL of $\mathrm{OB}$, reaching its maximum after 14 days of ADSCs administration. This could be attributed to the increased neuronal population which might have extended their processes and established synaptic circuits. Going with this suggestion, it was observed in a prior electron microscopic study that $\mathrm{OB}$ neurons received synapses from olfactory sensory axons in N-methyl-D-aspartate (NMDA)-induced OB injury ${ }^{[47]}$. In 2009, Sultan-Styne suggested that newborn granule cells normally become synaptically integrated over the first 2-4 weeks after their birth ${ }^{[48]}$.

Of notice, astrocytes were suggested to play a pivotal role in promoting OB neurogenesis. They might control the generation, migration, and survival of different subtypes of interneurons as well as the establishment of synaptic connections of newborn cells ${ }^{[49]}$. Moreover, the immunosuppressive effect of MSCs might lead to inhibition mature astrocytes ${ }^{[50]}$. Hence this might explain their relatively large number after one day of ADSCs treatment in group III of the present study with the ongoing ADSCS differentiation to neurons, and their subsequent reduction afterwards with concomitant increase in neuronal population in $\mathrm{OB}$

\section{CONCLUSION}

Intranasal administration of ADSCs had a relevant therapeutic potential on age-related structural changes of olfactory bulb. This route of administration might represent a novel valuable non-invasive tool for stem cell-based therapy that holds much promise in neuronal age-related structural changes. Using many time points to evaluate the experiment was of value to conclude that regeneration 
process was time-dependent. Further preclinical and clinical studies are needed to determine whether intranasal ADSCs-based therapies can fulfill clinical expectations for this age-related medical condition.

\section{CONFLICT OF INTEREST}

There are no conflicts of interest.

\section{REFERENCES}

1. Stevenson RJ. An initial evaluation of the functions of human olfaction. Chem Senses 2010; 35: 3-20.

2. Mobley AS, Rodriguez-Gil DJ, Imamura F, Greer CA. Aging in the olfactory system. Trends Neuroscience 2014; 37: 77-84.

3. Murphy C, Schubert CR, Cruickshanks KJ, Klein BE, Klein R, Nondahl DM. Prevalence of olfactory impairment in older adults. JAMA 2002; 288, 2307-2312.

4. Hummel T, Nordin S. Olfactory disorders and their consequences for quality of life-a review. Acta Oto-Laryngol 2005; 125: 116-21.

5. Attems J, Walker L, Jellinger KA. Olfaction and Aging: A Mini-Review. Gerontology 2015;61(6): 485-90.

6. Attems J, Walker L, Jellinger KA. Olfactory bulb involvement in neurodegenerative diseases. Acta Neuropathol 2014; 127: 459-475.

7. Alves J, Petrosyan A, Magalhaes R. Olfactory dysfunction in dementia. World $\mathrm{J}$ Clin Cases 2014; 2 : 661-667.

8. Baddour JA, Sousounis K, Tsonis PA. Organ repair and regeneration: an overview. Birth Defects Res. C Embryo Today 2012; 96(1): 1-29.

9. Mitrecic D, Nicaise C, Klimaschewski L, Gajovic S, Bohl D, Pochet R. Genetically modified stem cells for the treatment of neurological diseases. Front Biosci (Elite Ed.) 2012; 4: 1170-1181.

10. Bourin P, Bunnell BA, Casteilla L, Dominici M. Katz AJ, March KL, Redl H, Rubin JP, Yoshimura K, Gimble JM. Stromal cells from the adipose tissue-derived stromal vascular fraction and culture expanded adipose tissue-derived stromal/ stem cells: a joint statement of the International Federation for Adipose Therapeutics and Science (IFATS) and the International Society for Cellular Therapy (ISCT). Cytotherapy 2013; 15(6): 641-648.
11. Chang KA, Kim HJ, Joo Y, Ha S, Suh YH. The therapeutic effects of human adipose-derived stem cells in Alzheimer's disease mouse models. Neurodegener Dis 2014;13: 99-102

12. Hanson LR, Frey WH. Intranasal delivery bypasses the blood-brain barrier to target therapeutic agents to the central nervous system and treat neurodegenerative disease. BMC Neurosci 2008; Dec 10;9 Suppl 3:S5.

13. Reitz M, Demestre M, Sedlacik J, Meissner H, Fiehler J, Kim S, Westphal M, Schmidt N. Intranasal Delivery of Neural Stem/Progenitor Cells: A Noninvasive Passage to Target Intracerebral Glioma Stem Cells Translational Medicine 2012; 1: 866-873

14. Danielyan L, Schäfer, R, von Ameln-Mayerhofer, A, Bernhard, F, Verleysdonk, S, Buadze, M, Lourhmati A, Klopfer T, Schaumann F, Schmid B, Koehle C, Proksch B, Weissert R, Reichardt HM, Brandt JVD, Buniatian GH, Schwab M, Gleiter CH, Frey II WH. Therapeutic efficacy of intranasally delivered mesenchymal stem cells in a rat model of Parkinson disease. Rejuvenation Res. 2011; 14: 3-16.

15. Suvarna SK, Layton C, Bancroft JD. Bancroft's theory and practice of histological techniques, 7th edition, Churchill Livingstone, UK, El Sevier 2013; pp: 408, 504.

16. Tahir SM, Lone KP. Age and gender-related differences in mitral cells of olfactory bulb. J Coll Physicians Surg Pak 2008;18(11): 669-73

17. Kass MD, Czarnecki LA, Moberly AH, McGann JP. Differences in peripheral sensory input to the olfactory bulb between male and female mice. Sci. Rep. 2017;26(7): 45851

18. Romano RC, Carter JM, Folpe AL. Aberrant intermediate filament and synaptophysin expression is a frequent event in malignant melanoma: an immunohistochemical study of 73 cases. Mod Pathol 2015;28(8): 1033-42.

19. Astic L., Saucier D. Neuronal plasticity and regeneration in the olfactory system of mammals: Morphological and functional recovery following olfactory bulb deafferentation. Cell Mol Life Sci 2001; 58: 538-45.

20. Salihoglu M, Kendirli MT, Altundag A, Tekeli H, Saglam M, Cayonu M, Senol MG, Ozdag F. The effect of obstructive sleep apnea on olfactory functions Laryngoscope 2014 Sep;124(9):2190-4. 
21. Thomann PA, Dos SV, Seidl U, Toro P, Essig M, Schroder J. MRI-derived atrophy of the olfactory bulb and tract in mild cognitive impair- ment and Alzheimer's disease. J. Alzheimers Dis 2009; 17: 213-221.

22. Brodoehl S, Klingner C, Volk GF, Bitter T, Witte OW, Redecker C. Decreased olfactory bulb volume in idiopathic Parkinson's disease detected by 3.0-Tesla magnetic resonance imaging. Mov Disord 2012; 27: 1019-1025.

23. Nguyen AD, Pelavin PE, Shenton ME, Chilakamarri P, McCarley RW, Nestor PG, Levitt JJ. Olfactory sulcal depth and olfactory bulb volume in patients with schizophrenia: an MRI study. Brain Imag. Behav 2011; 5: 252-261.

24. Sakamoto M, Kageyama R, Imayosh I. The functional significance of newly born neurons integrated into olfactory bulb circuits. Frontiers in neuroscience 2014; 8(121): 1-9

25. Jin K, Sun Y, Xie L, Batteur S, Mao XO, Smelick C, Logvinova A, Greenberg D. Neurogenesis and aging: FGF-2 and HB-EGF restore neurogenesis in hippocampus and subventricular zone of aged mice. Aging Cell 2003; 2: 175-183

26. Conover JC, Shook BA. Aging of the subventricular zone neural stem cell niche. Aging Dis 2011; 2: 49-63.

27. Whitman MC, Fan W, Rela L, Rodriguez-Gil DJ, Greer CA. Blood vessels form a migratory scaffold in the rostral migratory stream. J Comp Neurol 2009; 516: 94-104.

28. Mombaerts P. Axonal wiring in the mouse olfactory system. Annu Rev Cell Dev Biol 2006; 22: 713-737.

29. Richard MB, Taylor SR, Greer CA. Ageinduced disruption of selective olfactory bulb synaptic circuits. Proc Natl Acad Sci 2010; 107: 15613-15618.

30. O'Connor S, Jacob TJ. Neuropharmacology of the olfactory bulb. Curr Mol. Pharmacol 2008; 1, 181-190.

31. Rusnakova V, Honsa P, Dzamba D, Ståhlberg A, Kubista M, Anderova M. Heterogeneity of astrocytes: from development to injury-single cell gene expression. PLoS One 2013;8(8): e69734.

32. Sofroniew MV. Multiple roles for astrocytes as effectors of cytokines and inflammatory mediators.
Neuroscientist 2013; 20: 160-172.

33. McIntosh K, Zvonic S, Garrett S, Mitchell JB, Floyd ZE, Hammill L, Kloster A, Halvorsen YD, Ting JP, Storms RW, Goh B, Kilroy G, Wu $\mathrm{X}$, Gimble JM. The immunogenicity of human adipose derived cells: temporal changes in vitro. Stem Cells 2006; 24: 1245-1253.

34. Puissant B, Barreau C, Bourin P, Clavel C, Corre J, Bousquet C, Taureau C, Cousin B, Abbal M, Laharrague P, Penicaud L, Casteilla L, Blancher A. Immunomodulatory effect of human adipose tissue-derived adult stem cells: comparison with bone marrow mesenchymal stem cells. $\mathrm{Br} \mathrm{J}$ Haematol 2005; 129: 118-129.

35. Hardy W, Devine S, Ucker D, Deans R, Moseley A, Hoffman R. Mesenchymal stem cells suppress lymphocyte proliferation in vitro and prolong skin graft survival in vivo. Exp Hematol $2002 ; 30: 42-48$.

36. Cruz YD, Támos YM, Cernuda AM, Martines NS, González-Quevedo A, Testé IS Rodríguez JCG. Treatment with Nasal Neuro-EPO Improves the Neurological, Cognitive, and Histological State in a Gerbil Model of Focal Ischemia the scientific world journal 2010;10: 2288-2300

37. Alcalá-Barraza SR, Lee MS, Hanson LR, McDonald AA, Frey II WH, McLoon LK. Intranasal delivery of neurotrophic factors BDNF, CNTF, EPO, and NT-4 to the CNS. J Drug Target 2010; 18(3): 179-190

38. Balyasnikova IV, Prasol MS, Ferguson SD, Han Y, Ahmed AU, Gutova M, Tobias AL, Mustafi D, Rincón E, Zhang L, Aboody KS, Lesniak MS. Intranasal Delivery of Mesenchymal Stem Cells Significantly Extends Survival of Irradiated Mice with Experimental Brain Tumors. The American Society of Gene \& Cell Therapy 2014; 22 (1): 140-148

39. Van Velthoven CT, Kavelaars A, van Bel F, Heijnen CJ. Mesenchymal stem cell transplantation changes the gene expression profile of the neonatal ischemic brain. Brain Behav Immun 2011; 25: $1342-1350$

40. Zuk PA, Zhu M, Ashjian P, De Ugarte DA, Huang JI, Mizuno H, Alfonso ZC, Fraser JK, Benhaim P, Hedrick MH. Human adipose tissue is a source of multipotent stem cells. Mol Biol Cel 2002; 13: 4279e4295.

41. Safford KM, Safford SD, Gimble JM, Shetty 
AK, Rice HE. Characterization of neuronal/glial differentiation of murine adipose-derived adult stromal cells. Exp Neurol 2004; 187: 319-328.

42. Kim JM, Lee ST, Chu K Jung KH, Song EC, Kim SJ, Park DK, kang KM, Hyung Hong N, Park $\mathrm{KH}$, Won CH, Kim KH, Kim M, Kun Lee S, Roh JK. Systemic transplantation of human adipose stem cells attenuated cerebral inflammation and degeneration in a hemorrhagic stroke model. Brain Res 2007;1183: 43-50.

43. Kang SK, Shin MJ, Jung JS, Kim YG, Kim CH. Autologous adipose tissue-derived stromal cells for treatment of spinal cord injury. Stem Cells Dev 2006; 15: 583-594.

44. Roybon L, Mastracci TL, Li J, Stott SRW, Leiter AB, Sussel L, Brundin P, Li JY. The Origin, Development and Molecular Diversity of Rodent Olfactory Bulb Glutamatergic Neurons Distinguished by Expression of Transcription Factor NeuroD1. PLoS ONE 2015;10(6): e0128035.

45. Brill MS, Ninkovic J, Winpenny E, Hodge RD, Ozen I, Yang R, Lepier A, Gascón S, Erdelyi F, Szabo G, Parras C, Guillemot F, Frotscher M, Berninger B, Hevner RF, Raineteau O, Götz M. Adult generation of glutamatergic olfactory bulb interneurons. Nat Neurosci 2009; 12(12):1524-33.
46. Donega V, Nijboer CH, van Tilborg G, Dijkhuizen RM, Kavelaars A, Heijnen CJ. Intranasally administered mesenchymal stem cells promote a regenerative niche for repair of neonatal ischemic brain injury. Exp Neurol 2014; 261: 53-64.

47. Gimble JM, Katz AJ, Bunnell BA. AdiposeDerived Stem Cells for Regenerative Medicine. Circ Res 2007;100: 1249-1260

48. Sultan-Styne K, Toledo R, Walker C, Kallkopf A, Ribak CE, Guthrie KM. Long-term survival of olfactory sensory neurons after target depletion. J Comp Neurol. 2009; 515: 696-710

49. Yamaguchi M, Mori K. Critical periods for sensory experience-dependent survival of newly generated granule cells in the adult mouse olfactory bulb. Proc Natl Acad Sci USA. 2005; 102: 9697-702.

50. Gengatharan A, Bammann RR, Saghatelyan A. The Role of Astrocytes in the Generation, Migration, and Integration of New Neurons in the Adult Olfactory Bulb. Front Neurosci 2016; 10: Article 149.

51. Kokaia Z, Martino G, Schwartz , Lindvall O. Cross-talk between neural stem cells and immune cells: the key to better brain repair? Nat. Rev. Neurosci. 2012; 15, 1078-1087. 
الملخص العربى

\section{تأثير الخلايا الجذعية المستخلصة من النسيج الدهني المعطاه في الأنف على التغييرات المتعلقة

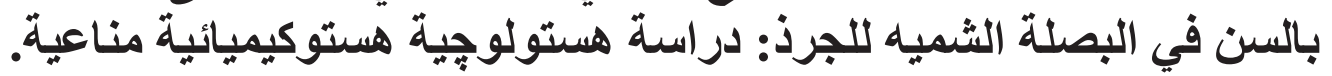

\section{نيقين بهاء، منى حسين رأفت}

\section{قسم الهستولوجيا وبيولوجيا الظلية، كلية الطب، جامعة عين شمس، القاهرة، مصر}

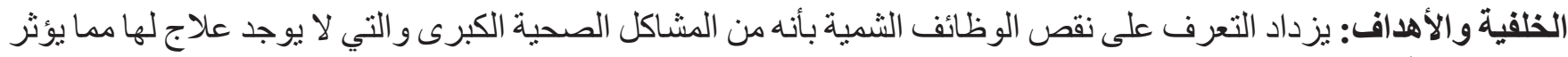

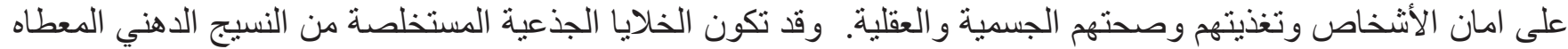

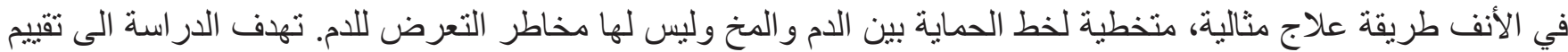

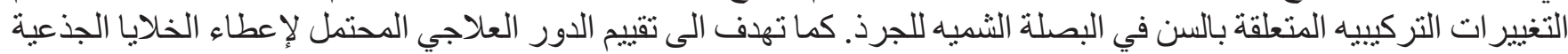

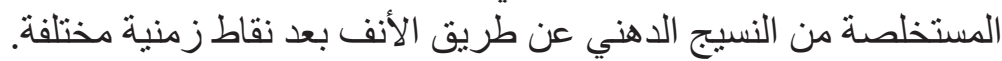

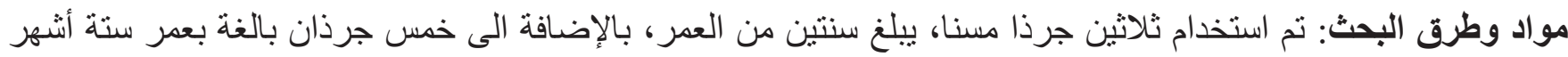

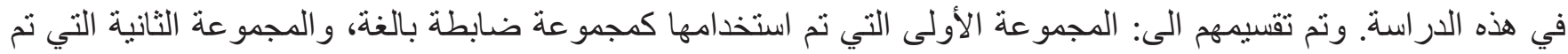

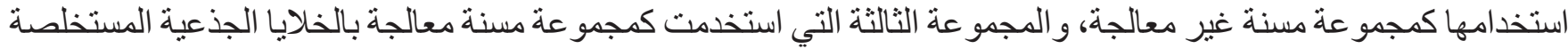

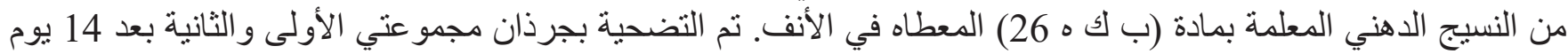

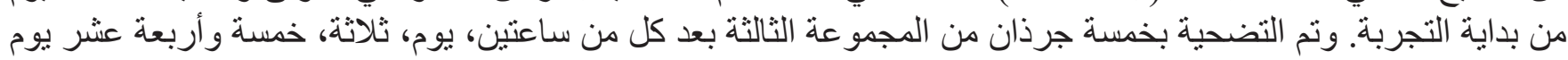

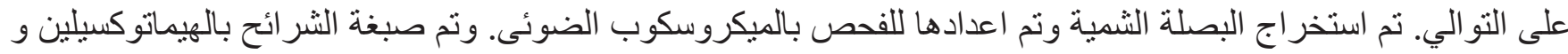

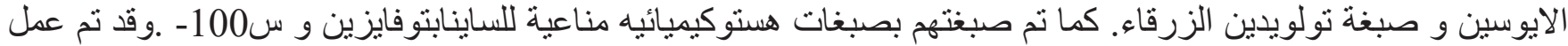

در اسه هستولوجية شكلية و تحاليل إحصائية أيضا.

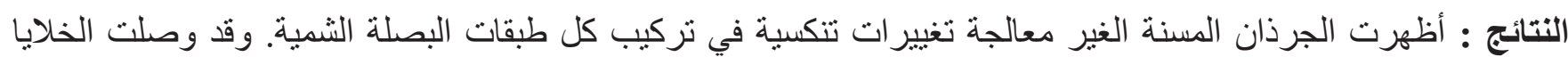

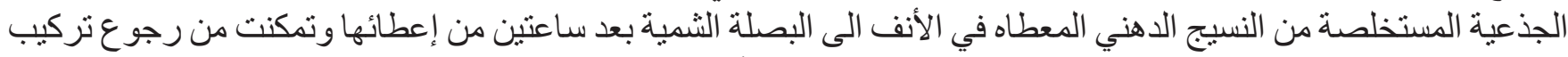

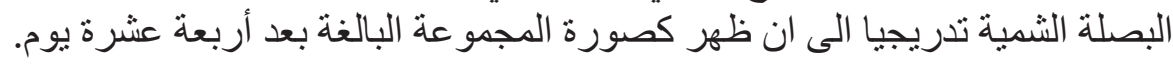

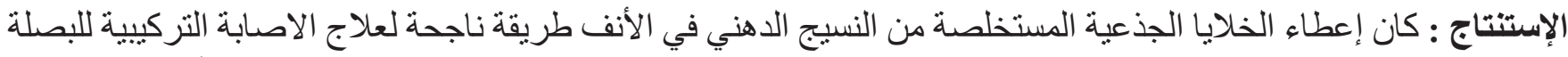

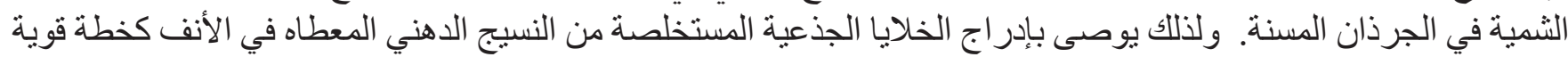
لعلاج للخلل الوظيفي للبصلة الثمية الناتج عن الثيخوخة. 